\title{
Interventional Techniques in the Management of Chronic Pain: Part 1.0 From The Association of Pain Management Anesthesiologists
}

\author{
Laxmaiah Manchikanti, MD*, Vijay Singh, MD^, Cyrus E. Bakhit*, MD, and Bert Fellows, MA**
}

\section{Disclaimer}

The following guidelines are meant to provide practical considerations for the use of interventional techniques in the management of chronic pain based on the current state of the art and science of interventional pain management. Hence, these guidelines do not constitute inflexible treatment recommendations. It is expected that a provider will establish a plan of care on a case by case basis taking into account an individual patient's medical condition, personal needs, and preferences, and the physician's experience. Based on an individual patient's needs, treatment different from that outlined here will be warranted.

The practice guidelines for interventional techniques in the management of chronic pain are systematically developed statements to assist practitioner and patient decisions about appropriate health care related to chronic pain. These guidelines are professionally derived recommendations for practices in the diagnosis and treatment of chronic or persistent pain. They were developed utilizing a combination of evidence and consensus to improve quality of care, increase patient access, improve patient outcomes, improve appropriateness of care, improve efficiency and effectiveness, and achieve cost containment.
Included in the guidelines is a discussion of their purpose, rationale, importance, and methodology, and patient population, pathophysiologic basis, and various interventional techniques utilized in the management of chronic pain including rationale, outcomes, and cost effectiveness. They also describe the role of diagnostic blocks and therapeutic blocks with suggested algorithms for interventional techniques in the management of conservative care of chronic pain.

Keywords: Interventional techniques, neural blockade, chronic pain, epidural injections, percutaneous epidural adhesiolysis, discography, facet joint mediated pain, radiofrequency.
The Association of Pain Management Anesthesiologists (AOPMA) guidelines for interventional techniques in the management of chronic pain were developed by a multidisciplinary team of professionals. The core group of members included Laxmaiah Manchikanti, MD; Cyrus E.

*Dr. Manchikanti is Executive Director and President of Association of Pain Management Anesthesiologists. ${ }^{\star D}$. Singh and Dr. Bakhit are Life Members and Directors of the Association of Pain Management Anesthesiologists. **Mr. Fellows is the Coordinator of the Association of Pain Management Anesthesiologists. Address Correspondence: Laxmaiah Manchikanti, MD, 2831 Lone Oak Road, Paducah, KY 42003
Bakhit, MD; Rajgopal R. Pakanati, MD; Vijay Singh, MD; Ramesh Amara, MD*; Abu Matin, MD*; Bert Fellows, $\mathrm{MA}^{\S}$; Patricia Burks, LPT $\sim$; Carla Beyer, $\mathrm{RN}^{\dagger}$; and Kim Damron, $\mathrm{RN}^{\dagger}$.

Following the initial preparation, the guidelines were reviewed by the following members of AOPMA which included physicians specializing in pain management, as well as others, including attorneys and practice management consultants.

* Internist; ${ }^{\S}$ Psychologist; Physical Therapist; ${ }^{\dagger}$ Registered Nurse; ${ }^{\dagger}$ Physician’s Assistant; $\$$ Physical Therapy Assistant; Attorney; ${ }^{* *}$ Practice Management Consultant; All Others are Interventional Pain Specialists 
The reviewers included Bentley A. Ogoke, MD; David M. Schultz, MD; Ballard D. Wright, MD; Peter D. Wright, MD; Steven R. Hayes, MD; Saadat Kamran, MD; Jacob Handszer, MD; M. Ramos Ferdinand, MD; Kent P. Weinmeister, MD; William Mangino, MD; Allan T. Parr, MD; Francis J. Abdou, MD; Kunnathu P. Geevarghese, MD; Bharat C. Shah, MD; Bruce J. Skolnik, MD; Roger W. Kemp, MD; Boris I. Pilch, MD; William L. Weigel, MD; Solomon Kamson, MD; A. Ghafoor Baha, MD; Jose Rivera, MD; David Kloth, MD; Andrea Trescot, MD; Mary Jo Curran, MD; Kenneth Varley, MD, Neeraj Jain, MD, William A. Sarraille, JD ; Allison W. Shuren, NP, JD ; Dan Johnson $^{* *}$; Della Croft, PA ${ }^{\dagger \dagger}$; and Jamie Day, PTA ${ }^{\S}$. Multiple comments and suggestions were received from members; these were incorporated into the final draft.

The guidelines were reviewed at the board meeting of AOPMA on January 5, 2000, and were approved unanimously. Those who were in attendance at the board meeting were Laxmaiah Manchikanti, MD; Andrea Trescot, MD; Kenneth Varley, MD; Thomas D. Falasca, DO; Cyrus E. Bakhit, MD; David Kloth, MD; Craig R. DuBois, MD; Bentley A. Ogoke, MD; Kendall Hansen, MD; and Vijay Singh, MD.

The dates for implementation and review were established:

- $\quad$ Effective date - February 1, 2000

- $\quad$ Expiration date - December 31, 2000

- $\quad$ Scheduled review - July 1, 2000.

\section{PURPOSE}

Clinical practice guidelines are commonly defined as "systematically developed statements to assist practitioner and patient decisions about appropriate health care for specific clinical circumstances" (1). The practice guidelines are professionally derived recommendations for practices for prevention, diagnosis, treatment, and in some cases, disability management. These clinical practice guidelines for interventional techniques in the management of chronic pain are professionally developed utilizing a combination of evidence and consensus. The purpose of these clinical guidelines is to:

1. Improve quality of care

2. Improve patient access

3. Improve patient outcomes

4. Improve appropriateness of care

5. Improve efficiency and effectiveness
6. Achieve cost containment by improving cost benefit ratio

\section{RATIONALE AND IMPORTANCE}

The most compelling single reason for the development of these clinical practice guidelines is to improve the quality of pain management, and thus the quality of life of pain sufferers. Available evidence documents a wide degree of variance in the practice of interventional pain management and pain medicine for even the most commonly performed procedure(s) or most commonly treated condition(s) (2-14). These guidelines also will address the issue of systematic evaluation and ongoing care of chronic or persistent pain, and will provide information about the scientific basis of recommended procedures, thus potentially increasing compliance, dispelling misconceptions among providers and patients, managing patient expectations reasonably, and forming the basis of a therapeutic partnership between the patient, the provider, and the payer.

Interventional techniques are crucial both in the diagnostic, as well as the therapeutic, arena of managing pain and providing improvement in the quality of life of the pain sufferers. Due to lack of either conclusive evidence or consensus and because of a wide variation in treatment protocols from practice to practice (and often within a practice) pain management has been incorrectly characterized, often negatively, by some insurance carriers and some other specialties.

\section{METHODOLOGY}

The two most common methods for the development of guidelines which are often combined, are based on evidence and consensus. These guidelines are a blend of both methodologies. However, evidence as well as consensus has been criticized in the literature $(15,16)$. The issues of ethics, feasibility, cost, and reliability pose challenges to the randomized trial, which theoretically represents the "gold standard" in interventional pain management (17-24). Due to the poor methodological quality of a large number of published randomized clinical trials on the efficacy of interventions in the management of low back pain, whiplash, and other painful conditions, the authors focused their work on those which consisted of studies well-controlled or high-quality uncontrolled studies with the emphasis on well-controlled studies when available. The focus of these guidelines is physiological, sup- 
ported by peer-review literature, and based on the best cost benefit balance for the patient in both the short and long term, and consensus.

\section{POPULATION}

The population covered by these guidelines includes all the patients who are suffering with chronic pain of either spinal or non-spinal origin eligible to undergo interventional technique.

\section{CHRONIC PAIN}

"Pain" as John Bonica, father of pain medicine observed in 1974, "is the most pressing issue of modern times." In spite of the best efforts of the public, providers and the government, pain continues to be an epidemic (25, 26). The knowledge and understanding of this complex entity, including diagnosis and treatment, is in its infancy, in spite of modern developments in medicine. Providers, patients, and the government all understand the devastating nature of chronic pain which destroys the quality of life by eroding the will to live, disturbing sleep and appetite, creating fatigue, and impairing recovery from illness or injury (25-27). In elderly patients it may make the difference between life and death by resulting in vocational, social, and family discord (28-30). Pahor et al (30) found that pain relief is particularly elusive for older women with disabling back and lower extremity problems. In this study, approximately two-thirds of the women reported significant levels of pain and difficulty in controlling it.

The concept of chronic pain is beset with controversy starting with its very definition. For some chronic painful conditions, it is defined as, "pain that exists beyond an expected time frame for healing." For other conditions, it is recognized that "healing may never occur." Bonica defined chronic pain as, "Pain which persists a month beyond the usual course of an acute disease or a reasonable time for any injury to heal that is associated with chronic pathologic processes that causes a continuous pain or pain at intervals for months or years" (31). In many cases, chronic pain is understood as persistent pain that is not amenable to routine pain control methods. Two major and controversial terms in today's pain medicine are "chronic pain," also known as persistent pain, and a second category known as "chronic pain syndrome," which is a separate and distinct condition $(32,33)$. Chronic pain syndrome is associated with major psychological and behavioral problems with or without a physical problem. Recurrent pain represents the nidus of chronic pain syndrome.
While chronic pain may be associated with psychological problems such as depression, generalized anxiety disorder, and some behavioral problems, chronic pain syndrome, in contrast is a malevolent and destructive force $(32,33)$. It is a self-sustaining, self-reinforcing, self-regenerating process, with markedly enhanced perception and with maladaptive and grossly disproportional pain related behavior. However, the literature shows that chronic pain syndrome is not a common phenomenon in general and it is particularly very infrequent in the elderly (34). In addition, Hendler et al (35), to whom a number of suspected "psychosomatic" cases have been referred, found organic origin of the pain in $98 \%$ of cases. Subsequently, Hendler and Kolodny (36) estimated that the incidence of psychogenic pain is only 1 in 3000 patients.

Chronic pain has been estimated to cost the American society approximately $\$ 120$ billion a year in treatment, lost revenues, and wages. Some frightening estimates show that annual total costs for back pain itself, including disability and litigation, are more than $\$ 100$ billion (37). Annual direct medical costs for back pain are estimated at around $\$ 33$ billion with chronic pain around $\$ 45$ billion. Approximately $28 \%$ to $30 \%$ of the United States population suffer with some kind of chronic painful condition(s) (25-61). Pain of spinal origin effects $80 \%$ of the population at some point during their life span. As many as 35\% to $79 \%$ of the patients may suffer back pain and disability for over one year after its initial onset, contrary to the traditional belief that most back pain is cured in 60 days (56-61).

The tragedy of needless pain and suffering can be avoided to a great extent by appropriate utilization of interventional techniques in managing chronic pain and other non invasive modalities.

\section{PATHOPHYSIOLOGIC BASIS}

Two major categories of pain are: pain of spinal origin, and pain of non-spinal origin.

Spinal pain is inclusive of all painful conditions originating from spinal structures ranging from the discs to muscles and ligamentous attachments. In contrast, nonspinal pain encompasses a multitude of other painful conditions ranging from peripheral neuralgias to reflex sympathetic dystrophy and arthritis. Virtually every structure in the spine, as well as other organs, has been implicated as a possible source of pain at one or time another. Any structure with a nerve supply capable of causing pain simi- 
lar to that seen in clinically normal volunteers, which is susceptible to diseases or injuries that are known to be painful can cause pain $(2-4,13,14,62-95)$. Certain conditions may not be detectable using currently available technology or biochemical studies $(2,3,13,14,50,70,71$, $84,85,97-108)$. However, for a structure to be implicated, it should have been shown to be a source of pain in patients, using diagnostic techniques of known reliability and validity. The structures responsible for pain in the spine include the vertebrae, intervertebral discs, spinal cord, nerve roots, facet joints, ligaments, muscles, atlantooccipital joints, atlanto-axial joints, and sacroiliac joints. Similarly, muscles, ligaments, joints, sensory nerves, the sympathetic nervous system, and visceral organs have been implicated in pain of non spinal origin.

Even though disc herniation, strained muscles, and torn ligaments, have been attributed in the past to be the cause of most spinal pain either in the neck and upper extremities, upper and mid back, or low back and lower extremities, disorders of the spinal joints, which include facet joints, have been implicated more commonly than disc herniation, attributing some $50 \%$ of spinal pain to these joints $(13,14,72-85,93-95,109-120)$. Facet joints were described as a potential source of low back pain as early as 1911, 20 years earlier than ruptured disc. The existence of lumbar facet joint pain is supported by a preponderance of scientific evidence, even though a few detractors have disputed this. The prevalence of facet joint mediated pain in patients with chronic spinal pain has been established as $15 \%$ to $45 \%$ in low back pain, and $54 \%$ to $60 \%$ in neck pain utilizing controlled diagnostic blocks $(13,14,84,111-113,118-120)$.

The second most common structure responsible for pain in the spine is the intervertebral disc. Even though disc herniation is seen only in a small number of patients, degeneration of the disc resulting in primary discogenic pain is seen much more commonly. In contrast to ruptured disc where pain arises from the nerve root, in discogenic pain a disc with or without internal disruption is implicated rather than the nerve root $(65-69,86-92,121$ 127).

Post laminectomy syndrome or pain following operative procedures of the spine, sometimes known as failed management syndrome, is becoming a common entity in modern medicine (128-151). It is estimated that 20 to $30 \%$ of spinal surgeries, occasionally up to as high as $40 \%$, may not be successful as a result of either the surgery being inadequate, incorrect, or unnecessary; but also it may result following a well-indicated and well-performed surgical procedure. Even in cases of successful surgery, pain and subsequent disability have returned after variable periods from 6 months to 20 years. In these cases, scar-tissue development, destabilization of the spinal joints, and recurrent or repeat disc herniation may be responsible for continued pain problems. However, surgical results are extremely poor in patients after a failed surgical procedure (147). Other spinal conditions include various degenerative disorders such as spinal stenosis, spondylolysis, spondylolisthesis, degenerative scoliosis, idiopathic vertebrogenic sclerosis, diffuse idiopathic spinal hyperostosis, segmental instability; and multiple myofascial syndromes with involvement of muscles and ligaments. While degenerative conditions other than disc disruption and facet arthritis may contribute to approximately $5 \%$ to $10 \%$ of spinal pain, myofascial pain syndromes are not supported by a prevalence of epidemiological data $(100,101,152-$ 154).

The causes of non spinal pain include the various causes responsible for headache; trigeminal neuralgia with facial pain; cancer pain with involvement of various musculoskeletal structures either with the spread of the cancer into bones and muscles with compression of the spinal cord, or pain after multiple surgical procedures; pain secondary to pressure on various nerve plexuses resulting in neuropathic pain; and, finally, pain resulting from pathogenic visceral organs. Other causes include reflex sympathetic dystrophy and causalgia or complex regional pain syndromes Types I and II; postherpetic neuralgia, phantom limb pain; and finally, the controversial myofascial pain $(101,152-157)$.

\section{INTERVENTIONAL TECHNIQUES}

The history of the application of interventional techniques in pain management dates back to 1901 , when epidural injections for lumbar nerve root compression were reported (158-160). Since then, substantial advances have been made in the administration of epidural injections; and a multitude of other blocks and procedures have been devised $(2,3,13,14,161-174)$. Thus, neural blockade has been distinguished as the favored, at times decisive, intervention in the diagnostic and therapeutic management of chronic painful conditions.

The general benefits of the various types of nerve blocks including epidurals and neurolytic blocks include pain relief which out lasts by hours, days, and sometimes weeks the transient pharmacologic action of either local 
anesthetic or other agents provided. However, clear cut explanations for such benefits are not available. It is believed that neural blockade alters or interrupts nociceptive input, reflex mechanism of the afferent limb, self sustaining activity of the neuron pools and neuraxis, and the pattern of central neural activities (175). The explanations are based in part on the pharmacological and physical actions of local anesthetics, corticosteroids, and other agents. It is also believed that local anesthetics interrupt the pain-spasm cycle and reverberating nociceptor transmission, whereas corticosteroids reduce inflammation either by inhibiting the synthesis or release of the number of pro-inflammatory substances (176-182). Various modes of action of corticosteroids include membrane stabilization; inhibition of neural peptide synthesis or action; blockade of phospholipase $\mathrm{A}_{2}$ activity, prolonged suppression of ongoing neuronal discharge; suppression of sensitization of dorsal horn neurons; and reversible local anesthetic effect (177-189). In addition, local anesthetics have been shown to produce prolonged dampening of c-fiber activity (190-192). Physical effects include clearing adhesions or inflammatory exudates from the vicinity of the nerve root sleeve. The scientific basis of some of these concepts is proven for spinal pain management with epidural injections of betamethasone, and intravenous methylprednisolone $(181,184,185,187)$.

\section{Rationale}

The rationale for diagnostic neural blockade in the management of spinal pain stems from the fact that clinical features and imaging or neurophysiologic studies do not permit the accurate diagnosis of the causation of spinal pain in the majority of the patients in the absence of disc herniation and neurological deficit $(2,3,13,14,50$, $71,84,85,98-108,111-113)$. Further rationale is based on the recurring facts showing the overall rate of inaccurate or incomplete diagnosis in patients referred to pain treatment centers to range from $40 \%$ to $67 \%$, incidence of psychogenic pain to be only 1 in 3000 patients, and presence of organic origin of the pain in $98 \%$ of cases mistakenly branded as psychosomatic cases $(35,36)$. Finally, the most compelling reason is that chronic low back pain is a diagnostic dilemma in $85 \%$ of the patients even in experienced hands with all the available technology (Fig. 1). It has been determined that utilizing alternative means of diagnosis including precision diagnostic blocks in cases where there is a lack of definitive diagnostic radiologic or electrophysiologic criteria, can enable an examiner to identify the source of pain in the majority of patients, thus reducing the proportion of patients who cannot be given a definite diagnosis from $85 \%$ to $35 \%$ or even as low as $15 \%$.

Fig. 1. Pitfalls with conventional evaluation of low back pain

"Specific anatomic etiology is clearly and objectively identified in only $10 \%$ to $20 \%$."

1. Radiographic "abnormalities" are frequently clinically irrelevant.

2. True sciatica occurs in only 1 to $2 \%$ of the patients.

3. No universal criteria are established for scoring the presence, absence, or importance of particular signs.

4. Quantification of the degree of disability and the association to treatment outcomes is difficult.

5. Interpretation of biomedical findings relies on "clinical judgments," "physician's experience," and "quasistandardized criteria."

6. Routine clinical assessment is frequently subjective and unreliable.

7. Physical examination and diagnostic findings are subjective.

8. The discriminative power of common objective signs has been questioned.

9. Reliance on general "clinical impression" to detect gross psychological disturbances is "hopelessly inaccurate."

10. It is usually not possible to make a precise diagnosis or identify anatomic origin of the pain by routine clinical assessment.

Adapted and modified from Waddell and colleagues (103). 
The rationale for therapeutic interventional techniques, including neural blockade in the spine, is based upon several considerations: the cardinal source of chronic spinal pain, namely discs and joints, are accessible to neural blockade; removal or correction of structural abnormalities of the spine may fail to cure and may even worsen painful conditions; degenerative processes of the spine and the origin of spinal pain are complex; and the effectiveness of a large variety of therapeutic interventions in man- aging chronic spinal pain has not been demonstrated conclusively $(2,3,11-14,17,47,50,71,102-108,140,150$, 151, 154, 193-215).

Facet Joint Blocks: Facet joint blocks include facet joint injections, atlanto-occipital joints, atlanto-axial joints, and sacroiliac joints, or interruption of sensory nerve supply to these joints by neurolysis $(2,3,13,14,216-278)$. Facet joint-mediated pain is the single most common cause

Table 1. Results of published reports of effectiveness of facet joint injections

\begin{tabular}{|c|c|c|c|c|c|c|c|}
\hline \multirow[b]{2}{*}{ Study } & \multirow[b]{2}{*}{$\begin{array}{c}\text { Study } \\
\text { Characteristics }\end{array}$} & \multirow[b]{2}{*}{$\begin{array}{l}\text { No. of } \\
\text { Patients }\end{array}$} & \multirow[b]{2}{*}{$\begin{array}{l}\text { Drugs } \\
\text { Utilized }\end{array}$} & \multirow[b]{2}{*}{$\begin{array}{c}\text { Initial Relief } \\
\text { 1-4 weeks } \\
\text { Control vs Treatment }\end{array}$} & \multicolumn{2}{|c|}{$\begin{array}{c}\text { Long-term relief } \\
\text { Control vs Treatment }\end{array}$} & \multirow[b]{2}{*}{$\begin{array}{c}\text { Results } \\
\text { P - Positive } \\
\text { N - } \\
\text { Negative }\end{array}$} \\
\hline & & & & & 3 months & 6 months & \\
\hline \multicolumn{8}{|l|}{ Lumbar } \\
\hline Carette et al (259) & P, PC, RA & 101 & NS, LA, S & 33 vs $42 \%$ & $\mathrm{~N} / \mathrm{A}$ & $\begin{array}{c}15 \% \text { vs } \\
46 \%\end{array}$ & $\mathrm{~N}$ \\
\hline Lynch \& Taylor (271) & $\mathrm{P}, \mathrm{C}$ & 50 & LA, S & $50 \%$ vs $92 \%$ & $62 \%$ & $56 \%$ & $\mathrm{P}$ \\
\hline Murtagh (267) & $\mathrm{P}, \mathrm{C}$ & 100 & NS, LA & $94 \%$ & $54 \%$ & N/A & $\mathrm{P}$ \\
\hline Lewineck \& Warfield (266) & $\mathrm{R}$ & 21 & LA, S & $75 \%$ & $33 \%$ & N/A & $\mathrm{P}$ \\
\hline Lippit (264) & $\mathrm{R}$ & 99 & LA, S & N/A & $52 \%$ & N/A & $\mathrm{P}$ \\
\hline Lau et al (265) & $\mathrm{P}$ & 34 & LA, S & $56 \%$ & $44 \%$ & $35 \%$ & $\mathrm{P}$ \\
\hline Liliuss (270) & $\mathrm{P}, \mathrm{RA}, \mathrm{PC}$ & 109 & NS, LA, S & N/A & $64 \%$ & N/A & $\mathrm{P}$ \\
\hline Nash (217) & P, RA & 66 & LA, S & $58 \%$ & N/A & N/A & $\mathrm{N}$ \\
\hline Marks et al (216) & P, RA & 86 & $\mathrm{LA}<\mathrm{S}$ & $45 \%$ & $18 \%$ & N/A & $\mathrm{N}$ \\
\hline Mironer \& Somerville (113) & $\mathrm{C}$ & 148 & LA, S & $28 \%$ & $28 \%$ & N/A & $\mathrm{P}$ \\
\hline \multicolumn{8}{|l|}{ Cervical } \\
\hline Barnsley (256) & P, RA, PC & 41 & LA, S & $50 \%$ & $\mathrm{~N} / \mathrm{A}$ & $\mathrm{N} / \mathrm{A}$ & $\mathrm{N}$ \\
\hline Dory (272) & $\mathrm{R}$ & 14 & LA, S & $64 \%$ & $36 \%$ & N/A & $\mathrm{P}$ \\
\hline Roy et al (253) & $\mathrm{R}$ & 21 & LA, S & $91 \%$ & $62 \%$ & $\mathrm{~N} / \mathrm{A}$ & $\mathrm{P}$ \\
\hline
\end{tabular}


of spinal pain in $40 \%$ to $60 \%$ of the patients $(13,14,84$, 111-113, 118-120).

The specific rationale for facet-joint blocks is based on the observation that, if a particular joint is determined to be the source of pain generation, long-term relief can be sought by directing therapeutic interventions at that joint.

In managing low back pain, local anesthetic injection into the facet joints or interruption of the nerve supply to the facet joints has been accepted as the standard for diagnosis of facet-joint mediated pain. Since a single joint is innervated by at least two medial branches, two adjacent levels should always be blocked. Effectiveness of facet-joint injections, facet-joint nerve blocks, and facet-joint neurolysis has been reasonably studied, though the results have varied widely $(2,3,13,112,113,216-$ 218, 222-273). The evidence for lumbar intra-articular injections of steroids with or without local anesthetic is in favor of the injections in well-controlled studies, even though the evidence is not unequivocal (Table 1). Studies of intra-articular injections showed short-term relief in $46 \%$ to $75 \%$ of the patients, while long-term relief was seen only in $20 \%$ to $36 \%$ of the patients following a single injection. The role of medial branch blocks in the diagnosis of facet-joint pain has been well described and is considered superior to intra-articular comparative local anesthetic blocks. However, for therapeutic purposes, the literature is sparse and the few studies which do exist have reported that facet-joint injections and medial branch blocks are of equal value $(13,112,216-218)$. Multiple reports showing the effectiveness of radiofrequency neurolysis were encouraging (Table 2).

In contrast, most of the positive results of cervical intra-articular injection of corticosteroids and medial branch blocks were from uncontrolled reports. The most

Table 2. Results of published reports on effectiveness of radiofrequency neurolysis

\begin{tabular}{|c|c|c|c|c|c|c|}
\hline & \multirow[b]{2}{*}{$\begin{array}{c}\text { Study } \\
\text { Characteristics }\end{array}$} & \multirow[b]{2}{*}{$\begin{array}{l}\text { No. of } \\
\text { Patients }\end{array}$} & \multirow[b]{2}{*}{$\begin{array}{c}\text { Initial Relief } \\
\text { Control vs. Treatment } \\
1-4 \text { weeks }\end{array}$} & \multicolumn{2}{|c|}{$\begin{array}{l}\text { Long-term relief } \\
\text { Control vs. Treatment }\end{array}$} & \multirow[b]{2}{*}{$\begin{array}{c}\text { Results } \\
\text { P - Positive } \\
\text { N - Negative }\end{array}$} \\
\hline & & & & 3 months & 6 months & \\
\hline Lord et al (222) & $\begin{array}{c}\text { Cervical } \\
\text { P, PC, RA }\end{array}$ & 24 & N/A & N/A & $58 \%$ & $\mathrm{P}$ \\
\hline Van Kleef, et al (247) & $\begin{array}{c}\text { Lumbar } \\
\text { P, DB, RA }\end{array}$ & 31 & $38 \%$ vs. $67 \%$ & $25 \%$ vs. $66 \%$ & $19 \%$ vs. $47 \%$ & $\mathrm{P}$ \\
\hline Dreyfuss et al (235) & $\begin{array}{l}\text { Lumbar } \\
\quad P\end{array}$ & 15 & N/A & $87 \%$ & $80 \%$ & $\mathrm{P}$ \\
\hline Gallagher et al (230) & $\begin{array}{l}\text { Lumbar } \\
\text { P, PC }\end{array}$ & 30 & $17 \%$ vs. $42 \%$ & N/A & $24 \%$ vs. $41 \%$ & $\mathrm{P}$ \\
\hline North et al (228) & $\begin{array}{l}\text { Lumbar } \\
\quad \mathrm{R}\end{array}$ & 40 & N/A & N/A & $13 \%$ & $\mathrm{~N}$ \\
\hline Sluijter (172) & $\begin{array}{c}\text { Cervical } \\
\mathrm{R}\end{array}$ & 64 & $63 \%$ & $63 \%$ & N/A & $\mathrm{P}$ \\
\hline Schaerer (229) & $\begin{array}{c}\text { Cervical } \\
\mathrm{R}\end{array}$ & 50 & N/A & $50 \%$ & $50 \%$ & $\mathrm{P}$ \\
\hline Schaerer (229) & $\begin{array}{c}\text { Lumbar } \\
\text { R }\end{array}$ & 71 & N/A & $35 \%$ & $35 \%$ & $\mathrm{P}$ \\
\hline Burton (240) & $\begin{array}{l}\text { Lumbar } \\
\quad \mathrm{R}\end{array}$ & 126 & N/A & $67 \%$ & $67 \%$ & $\mathrm{P}$ \\
\hline $\begin{array}{l}\text { Mironer and Somerville } \\
\text { (113) }\end{array}$ & $\begin{array}{l}\text { Lumbar } \\
\quad \mathrm{P}\end{array}$ & 29 & $79 \%$ & $79 \%$ & $79 \%$ & $\mathrm{P}$ \\
\hline
\end{tabular}

P - Prospective PC - Placebo Controlled RA - Randomized R - Retrospective DB - Double Blind 
comprehensive data are available for percutaneous radiofrequency neurotomy for chronic cervical facet joint-mediated pain. A multitude of other uncontrolled reports of percutaneous radiofrequency neurotomy in the cervical spine also are encouraging (Table 2).

Epidural Injections: Approaches available to access the epidural space are interlaminar (cervical, thoracic, and lumbar), transforaminal (cervical, thoracic, lumbar, and sacral), and caudal (2-4, 274-276). The perceived advantages of each of the three approaches include $(2-4,277$ 282):

1. The interlaminar entry is directed more closely to the assumed site of pathology, facilitating delivery of the injectate directly to its target and requiring less volume;

2. The caudal entry is relatively easily achieved, with minimal risk of inadvertent dural puncture; and

3. The transforaminal approach is target specific in fulfilling the aim of reaching the primary site of pathology.

The disadvantages of each of the three approaches include:

1. With caudal entry;

The necessity of injection of a substantial volume of fluid $(2,4,278,282)$;

- Unrecognized placement of the needle outside the epidural space in a substantial number of cases $(2,4,284,282-288)$;

2. With interlaminar entry, at the cervical, thoracic, or lumbar levels;

- Extradural placement of the needle may go unrecognized without fluoroscopic guidance $(2,4,278,286,288)$;

- It is possible that one may erroneously miss the targeted interspace by one or two levels without fluoroscopic guidance, specifically in the thoracic and lumbar regions $(2,288,290)$;

It may be necessary to position the needle one level below the site of suspected pathology due to preferential cranial flow of solutions in the epidural space $(2,289,290)$;

- There is also the potential for deviation of the needle toward the nondependent side, and difficulty may be encountered with placement of injectate below L5 for S1 nerve root involvement $(2,124,286$, 291);

- The trauma of the needle to the spinal cord may become a major issue in the cervical, thoracic, and upper lumbar regions (292-297);

- Potential risk of dural puncture, and post dural puncture headache as well as total spinal block (2-4).

3. With transforaminal entry;

- Potential risk of intraneural injection and neural trauma.

Effectiveness of epidural injections has been evaluated in numerous studies $(2-12,124,168,271-281$, 298-347). However, well-controlled randomized studies only exist for lumbar interlaminar epidural injections and caudal epidural injections. Most of these studies were performed by multiple speciality groups (rarely including pain specialists) and without radiographic control, except for transforaminal blocks. Epidural injections are used in management of various types of spinal pain, reflex sympathetic dystrophy, neuropathic pain, and postherpetic neuralgia (Tables 3 and 4). The studies in managing spinal stenosis have also had mixed results, with good results from caudal epidural steroid injections and poor results from lumbar interlaminar epidural injections.

Thus far, published evidence is balanced for caudal epidural steroids $(2,4,5,274,313)$, but does not support the use of blind interlaminar lumbar epidural steroids $(2,4,5,12,274,281,288,302,313)$, cervical epidural steroids $(3,4)$, or injection of morphine unequivocally in the management of chronic spinal pain. Evidence for transforaminal steroids, though encouraging, is not extensive $(2,4,5,277,313,341-347)$. Hence, a strong argument can be made for transforaminal epidural injections. In review of 13 trials meeting strict inclusion criteria, 5 studies involving caudal epidural steroids injections and 8 studies involving lumbar epidural steroid injections were reviewed (12). This evaluation showed that in evaluating the effi- 
Table 3. Results of published reports on caudal epidural steroid injections

\begin{tabular}{|c|c|c|c|c|c|c|c|c|}
\hline \multirow[b]{2}{*}{ Study } & \multirow[b]{2}{*}{$\begin{array}{c}\text { Study } \\
\text { Characteristics }\end{array}$} & \multirow[b]{2}{*}{$\begin{array}{l}\text { No. of } \\
\text { Patients }\end{array}$} & \multirow[b]{2}{*}{$\begin{array}{l}\text { Drugs } \\
\text { Utilized }\end{array}$} & \multirow[b]{2}{*}{$\begin{array}{l}\text { No. of } \\
\text { Injections }\end{array}$} & \multirow{2}{*}{$\begin{array}{c}\text { Initial Relief } \\
\text { Control vs. } \\
\text { Treatment }\end{array}$} & \multicolumn{2}{|c|}{$\begin{array}{l}\text { Long-term Relief } \\
\text { Control vs. Treatment }\end{array}$} & \multirow[b]{2}{*}{$\begin{array}{c}\text { Results } \\
+=\text { Positive } \\
-=\text { Negative }\end{array}$} \\
\hline & & & & & & 3 months & 6 months & \\
\hline Breivik et al (328) & P, RA, DB & 35 & $\begin{array}{l}\text { S, LA, } \\
\text { NS }\end{array}$ & $1-3$ & 25 vs. 63 & 20 vs. 50 & 20 vs. 50 & + \\
\hline $\begin{array}{l}\text { Bush \& Hillier } \\
\text { (329) }\end{array}$ & $\mathrm{P}, \mathrm{RA}, \mathrm{PC}, \mathrm{DB}$ & 23 & $\begin{array}{l}\text { NS, LA, } \\
\text { S }\end{array}$ & 2 & 100 & N/A & 64 vs. 83 & + \\
\hline Yates (333) & P, RA, PC, DB & 20 & $\begin{array}{l}\text { S, NS, } \\
\text { LA }\end{array}$ & $1-4$ & N/A & N/A & N/A & + \\
\hline Beliveau (334) & $\mathrm{P}, \mathrm{RA}$ & 48 & LA, S & $1-2$ & 70 vs. 75 & 70 vs. 75 & N/A & - \\
\hline Goebert et al (168) & $\mathrm{R}$ & 113 & S, LA & $1-5$ & N/A & 72 & N/A & + \\
\hline
\end{tabular}

ciency of caudal epidural injections, four studies were positive, whereas one was negative. However, for lumbar epidural injections, five out of eight studies showed negative response. The literature available on usage of cervical epidural steroids by interlaminar route is encouraging. However, all these studies were uncontrolled and retrospective in nature. The evidence for transforaminal epidural ste- roids is encouraging, though not overwhelming. Based on the pathophysiology of spinal pain, the rationale, and principle of delivering the medication to the site of pathology, the only appropriate method of choice in administering epidural steroid injections appears to be under fluoroscopy $(2-5,277,278,282-291,313,341-348)$.

Percutaneous Epidural Adhesiolysis: Percutaneous non-

Table 4. Results of published reports on lumbar epidural steroid injections

\begin{tabular}{|c|c|c|c|c|c|c|c|c|}
\hline \multirow[b]{2}{*}{ Study } & \multirow[b]{2}{*}{$\begin{array}{c}\text { Study } \\
\text { Characteristics }\end{array}$} & \multirow[b]{2}{*}{$\begin{array}{l}\text { No. of } \\
\text { Patients }\end{array}$} & \multirow[b]{2}{*}{$\begin{array}{l}\text { Drugs } \\
\text { Utilized }\end{array}$} & \multirow[b]{2}{*}{$\begin{array}{l}\text { No. of } \\
\text { Injections }\end{array}$} & \multirow{2}{*}{$\begin{array}{c}\begin{array}{c}\text { Initial Relief } \\
\text { Control vs. } \\
\text { Treatment }\end{array} \\
\text { 3-4 weeks (\%) }\end{array}$} & \multicolumn{2}{|c|}{$\begin{array}{l}\text { Long-term Relief } \\
\text { Control vs. Treatment }\end{array}$} & \multirow[b]{2}{*}{$\begin{array}{c}\text { Results } \\
+=\text { Positive } \\
-=\text { Negative }\end{array}$} \\
\hline & & & & & & $\begin{array}{c}3 \text { months } \\
(\%)\end{array}$ & $\begin{array}{c}6 \text { months } \\
(\%)\end{array}$ & \\
\hline Dilke et al (300) & P, RA, PC, DB & 100 & $\mathrm{CS}, \mathrm{S}$ & $1-2$ & 31 vs. 60 & 74 vs. 91 & N/A & + \\
\hline Ridley et al (303) & $\mathrm{RA}, \mathrm{PC}, \mathrm{DB}$ & 35 & $\mathrm{CS}, \mathrm{S}$ & $1-2$ & 19 vs. 90 & 19 vs. 90 & 65 & + \\
\hline Snoek et al (306) & P, RA, PC, DB & 51 & NS, S & 1 & 25 vs. 33 & N/A & N/A & - \\
\hline Carette et al (124) & $\mathrm{P}, \mathrm{RA}, \mathrm{PC}, \mathrm{DB}$ & 158 & NS, S & $1-3$ & 29 vs. 33 & No sign. dif. & $\begin{array}{l}\text { No sign. } \\
\text { dif. }\end{array}$ & - \\
\hline Berman et al (307) & $\mathrm{P}, \mathrm{C}$ & 367 & LA, S & 1 & N/A & $70 \%$ & 61 & + \\
\hline Rosen et al (315) & $\mathrm{R}$ & 40 & S, LA & $1-5$ & 60 & N/A & 24 & + \\
\hline Warr et al (309) & $\mathrm{P}, \mathrm{C}$ & 500 & S, LA & $1-2$ & 63 & 63 & 63 & + \\
\hline $\begin{array}{l}\text { Swerdlow and } \\
\text { Sayle-Creer (281) }\end{array}$ & $\mathrm{P}, \mathrm{RA}, \mathrm{PC}$ & 325 & $\begin{array}{l}\text { NS, } \\
\text { LA, S }\end{array}$ & 1 & 52 vs. 67 & N/A & N/A & + \\
\hline Jamison et al (316) & $\mathrm{P}, \mathrm{C}$ & 249 & $\begin{array}{l}\mathrm{S}, \mathrm{LA} \text {, } \\
\mathrm{S}\end{array}$ & 1 & 62 & 62 & 62 & + \\
\hline Cuckler et al (299) & P, RA, DB & 73 & $\begin{array}{l}\mathrm{S}, \mathrm{LA} \\
\mathrm{S}\end{array}$ & $1-2$ & 26 vs. 40 & N/A & 13 vs. 26 & - \\
\hline Harley (312) & $\mathrm{R}$ & 50 & NS, LA & $1-4$ & N/A & 66 & 66 & + \\
\hline Rogers et al (318) & P, RA, DB & N/A & S, LA & 1 & & & & - \\
\hline
\end{tabular}


Table 5. Results of published reports of percutaneous lysis of adhesions and hypertonic saline neurolysis for a single procedure

\begin{tabular}{|c|c|c|c|c|c|c|c|}
\hline \multirow[b]{2}{*}{ Author(s) } & \multirow[b]{2}{*}{$\begin{array}{c}\text { Study } \\
\text { Characteristics }\end{array}$} & \multirow[b]{2}{*}{$\begin{array}{l}\text { No. of } \\
\text { Patients }\end{array}$} & \multirow[b]{2}{*}{ Drugs Used } & \multirow[b]{2}{*}{$\begin{array}{l}\text { No. of Days of } \\
\text { Procedure }\end{array}$} & \multirow[b]{2}{*}{$\begin{array}{c}\text { Initial } \\
\text { Relief } \\
\text { 1-4 weeks }\end{array}$} & \multicolumn{2}{|c|}{ Long-term Relief } \\
\hline & & & & & & 3 months & $\begin{array}{c}6 \\
\text { months }\end{array}$ \\
\hline $\begin{array}{l}\text { Racz and Holubec } \\
(350)\end{array}$ & $\mathrm{R}, \mathrm{RA}$ & 72 & $\mathrm{~B}, \mathrm{~T}, \mathrm{H}, \mathrm{HS}$ & 3 & $65 \%$ & $43 \%$ & $13 \%$ \\
\hline Arthur et al (355) & $\mathrm{R}$ & 50 & $\mathrm{~B}, \mathrm{~T}, \mathrm{HS}$ & 3 & $68 \%$ & N/A & $14 \%$ \\
\hline Arthur et al (355) & $\mathrm{R}$ & 50 & $\mathrm{~B}, \mathrm{~T}, \mathrm{H}, \mathrm{HS}$ & 3 & $82 \%$ & N/A & $12 \%$ \\
\hline $\begin{array}{l}\text { Manchikanti et al } \\
(356)\end{array}$ & $\mathrm{R}, \mathrm{RA}$ & 103 & M, L, HS & 2 & $74 \%$ & $37 \%$ & $21 \%$ \\
\hline $\begin{array}{l}\text { Manchikanti et al } \\
\text { (356) }\end{array}$ & $\mathrm{R}, \mathrm{RA}$ & 129 & M, L, HS & 1 & $79 \%$ & $26 \%$ & $14 \%$ \\
\hline $\begin{array}{l}\text { Manchikanti et al } \\
\text { (359) }\end{array}$ & $\mathrm{R}$ & 60 & L, HS, CS & 1 & $100 \%$ & $25 \%$ & $10 \%$ \\
\hline
\end{tabular}

endoscopic adhesiolysis and injection of hypertonic saline in the lumbar spine, its utilization and its studies have been reasonable and acceptable (349-360) (Tables 5 and $6)$. This modality of treatment appears to be reasonable in the management of refractory low back pain secondary to failed back surgery, disc disruption, and multilevel degenerative arthritis, even though there are a few detractors (360, 361).

Percutaneous epidural endoscopic adhesiolysis is also indicated for patients suffering with refractory low back pain secondary to a multitude of causes including post lumbar laminectomy syndrome, lumbar epidural fibrosis, and multilevel disc disruption, or multilevel de- generative arthritis $(359,362-364)$. However, this should only be used after the failure of the conservative modalities of treatments including caudal and transforaminal epidural injections. When available, epidural endoscopy should be the procedure of choice for lumbar epidural fibrosis.

Discography and Annuloplasty: Indication for disc injection and thermoneurolysis is a positive stimulation and analgesic response in the cervical spine and a positive disc stimulation in the lumbar spine (365-376). Evidence for thermal annuloplasty in the lumbar spine at the present time is equivocal and in its infancy (377-388). Currently, there is no role for intradiscal thermoneurolysis in the cer-

Table 6. Results of 1-year follow-up of patients percutaneous lysis of adhesions

\begin{tabular}{|c|c|c|c|c|c|c|c|}
\hline \multirow[b]{2}{*}{ Author(s) } & \multirow[b]{2}{*}{$\begin{array}{c}\text { Study } \\
\text { Characteristics }\end{array}$} & \multirow[b]{2}{*}{$\begin{array}{l}\text { No. of } \\
\text { Patients }\end{array}$} & \multirow[b]{2}{*}{$\begin{array}{l}\text { No. of Days of } \\
\text { Procedure }\end{array}$} & \multicolumn{4}{|c|}{ Percent of Patients with Significant Relief } \\
\hline & & & & 1 month & 3 months & 6 months & 12 months \\
\hline $\begin{array}{l}\text { Racz et al (357) and Heavner et } \\
\text { al (358) }\end{array}$ & $\mathrm{P}, \mathrm{C}, \mathrm{RA}$ & 59 & 3 & $83 \%$ & $49 \%$ & $43 \%$ & $49 \%$ \\
\hline Manchikanti et al (359) & $\mathrm{R}$ & 60 & 1 & $100 \%$ & $90 \%$ & $72 \%$ & $52 \%$ \\
\hline
\end{tabular}


Table 7. Pharmacologic profile of commonly used steroids

\begin{tabular}{lccccccc}
\hline & & & & Duration of Adrenal Suppression \\
\cline { 5 - 7 } Name of the Drug & $\begin{array}{c}\text { Equivalent } \\
\text { Dose }\end{array}$ & $\begin{array}{c}\text { Epidural } \\
\text { Dose }\end{array}$ & $\begin{array}{c}\text { Anti }- \\
\text { inflammatory } \\
\text { Potency }\end{array}$ & $\begin{array}{c}\text { Sodium } \\
\text { Retention } \\
\text { Capacity }\end{array}$ & IM & $\begin{array}{c}\text { Single } \\
\text { Epidural }\end{array}$ & $\begin{array}{c}\text { Three } \\
\text { Epidurals }\end{array}$ \\
\hline $\begin{array}{c}\text { Triamcinolone acetonide } \\
\text { (Kenalog) }\end{array}$ & $4 \mathrm{mg}$ & $40-80 \mathrm{mg}$ & 5 & 0 & $2-6$ weeks & N/A & $2-3$ months \\
$\begin{array}{c}\text { Betamethasone } \\
\text { (Celestone Soluspan) }\end{array}$ & $0.6 \mathrm{mg}$ & $6-12 \mathrm{mg}$ & 25 & 0 & $1-2$ weeks & N/A & N/A \\
$\begin{array}{c}\text { Triamcinolone diacetate } \\
\text { (Aristocort) }\end{array}$ & $4 \mathrm{mg}$ & $40-80 \mathrm{mg}$ & 5 & 0 & $1-2$ weeks & $1-5$ weeks & N/A \\
$\begin{array}{l}\text { Methylprednisolone acetate } \\
\text { (Depo-Medrol) }\end{array}$ & $4 \mathrm{mg}$ & $40-80 \mathrm{mg}$ & 5 & 0.5 & $1-6$ weeks & $1-3$ weeks & N/A \\
\hline $\begin{array}{l}\text { Adapted from Manchikanti (186) } \\
\text { IM = Intramuscular; N/A = Not Available }\end{array}$ & & & & & &
\end{tabular}

vical spine.

\section{Dosage, Frequency, and Number of Blocks}

There is no consensus among the interventional pain management specialists with regards to type, dosage, frequency, total number of injections, or other interventions $(2-13,389)$. Yet significant attention in the literature seems to be focused on the complications attributed to the use of epidural steroids in the entire arena of interventional pain management. Thus, various limitations of interventional techniques, specifically neural blockade, have arisen from basically false impressions. Based on the available literature and scientific application, the most commonly used formulations of long-acting steroids, which include methylprednisolone (Depomedrol ${ }^{\circledR}$ ), triamcinolone diacetate (Aristocort ${ }^{\circledR}$ ) triamcinolone acetonide (Kena$\left.\log ^{\circledR}\right)$, and betamethasone acetate and phosphate mixture (Celestone Soluspan ${ }^{\circledR}$ ) appear to be safe and effective (Table 7). The safety of the steroids and the preservatives at epidural therapeutic doses has been demonstrated in both clinical and experimental studies. Based on the present literature, it appears that if repeated within two weeks, betamethasone probably would be the best in avoiding side effects; whereas if treatment is carried out at six-week intervals or longer, any one of the four formulations will be safe and effective.

Frequency and total number of injections or interventions are a key issue, although controversial and rarely addressed. Some authors recommend one injection for diagnostic as well as therapeutic purposes; others advocate three injections in a series irrespective of the patient's progress or lack thereof; still others suggest three injections followed by a repeat course of three injections after 3-, 6-, or 12-month intervals; and, finally, there are some who propose an unlimited number of injections with no established goals or parameters. Limitation of $3 \mathrm{mg} / \mathrm{kg}$ of body weight of steroid or $210 \mathrm{mg}$ per year in an average person and a lifetime dose of $420 \mathrm{mg}$ of steroid, equivalent to methylprednisolone (Depomedrol) also have been advocated. While some investigators recommend one injection and do not repeat if there has been no response to the first, others recommend one or two more injections in the absence of response to the first injection. Some authors have reported good pain relief in previously unresponsive patients after an additional one or two injections. Similarly, some have believed that more than three injections do not result in additional improvement (308), whereas, others have reported the use of 6 to 10 injections if they are of benefit, however not to exceed 3 if they are not beneficial $(390,391)$. Such descriptions for other interventional techniques have been extrapolated from the limitations described for epidural steroid injections, even though there is no scientific basis or justification for such an extrapolation. It also has been shown in a multitude of publications that relief following multiple injections or interventions demonstrated a staircase-type phenomenon, even though it reached a plateau after three to four interventions.

\section{Outcomes and Cost Effectiveness}

Outcomes may be assessed by evaluation of the quality of life, which is also known as functional status, health status, health-related quality of life; well-being of 
Fig. 2 Cost effectiveness of selective therapies per quality-adjusted year of life gained

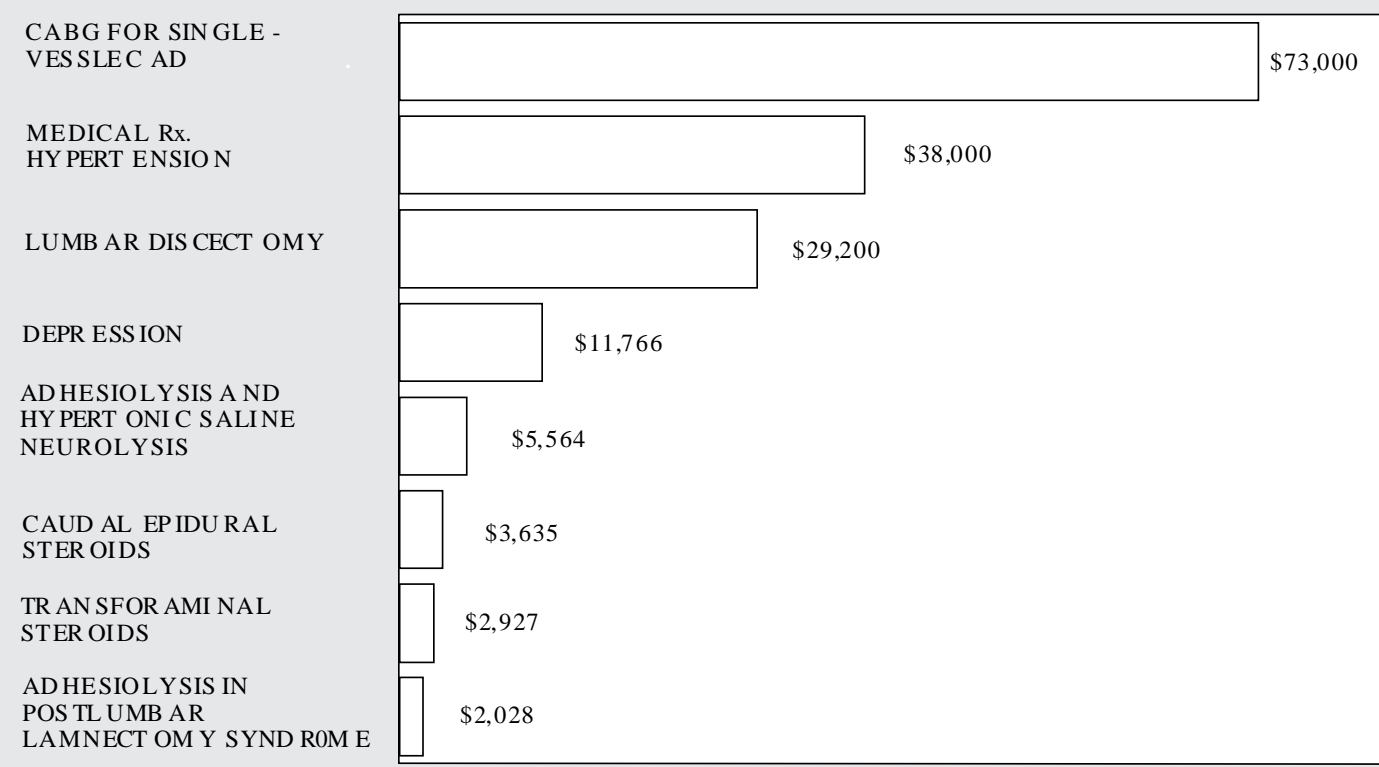

Data adapted and modified from Hopwood (392), Malter et al (194), Lave et al (406), and Manchikanti et al (313, 356, 359)

$\mathrm{CABG}=$ Coronary artery bypass graft

$\mathrm{CAD}=$ Coronary artery disease

the patient, satisfaction with care, health services utilization/economic analysis, and medical findings (392-400). The quality-of-life assessment is designed to evaluate the patient's abilities to function in his/her own world. Physical functioning measures the ability to perform physical activities such as walking, climbing stairs, or carrying things. Evaluation focuses on the patient's major perceived functional impairments, improvement in areas such as playing with children/grandchildren, having sexual relations, returning to work, going to school, homemaking or performing other activities of daily living. Quality of life also measures social functioning, which determines whether health problems affect normal social activities, such as seeing friends or participating in group activities.

It was shown that a simple reduction of diastolic pressure from 110 to $90 \mathrm{~mm} \mathrm{Hg}$ was achieved at a cost of $\$ 16,330$ for a 60 year-old man in 1974 (392). Costs of inpatient chronic pain programs range from $\$ 17,000$ to $\$ 25,000$ and the cost of outpatient treatment programs range from $\$ 7,000$ to $\$ 10,000$ (394). In addition, chronic pain patients may incur health care bills in excess of $\$ 20,000$ annually for repetitive and in some cases redundant diagnostic work-ups, physical therapy, psychologi- cal interventions, and drugs. The effectiveness of a multitude of interventions in managing chronic pain and improving functional outcomes has not been demonstrated as yet $(2,3,11-14,17,50,71,102-108,140,150,151$, $154,193-215,402,403)$. In a recent study, Guo and colleagues (404) estimated that back pain accounted for 150 million lost work days in the United States every year, which worked out to be about $\$ 14$ billion in wage costs alone. This study showed that the magnitude of the back pain problem is so large that even a $1 \%$ reduction in overall prevalence could considerably reduce morbidity and save billions of dollars. The cost-effectiveness of lumbar discectomy for the treatment of herniated intervertebral discs has been based on the conclusion that surgery increased the average quality-adjusted life expectancy by 0.43 years during the decade following treatment compared to conservative treatment, a result comparable to extending a healthy life by 5 months (194). It was also concluded that, for carefully selected patients with herniated discs, surgical discectomy is a cost-effective treatment at a discounted cost of $\$ 12,000$ per discectomy or $\$ 29,000$ per life year adjusted for quality (194). However, this study did not take into consideration the chronic pain patients when initial surgical treatment for herniated 
Fig. 3. Suggested algorithm for comprehensive evaluation and management of chronic pain

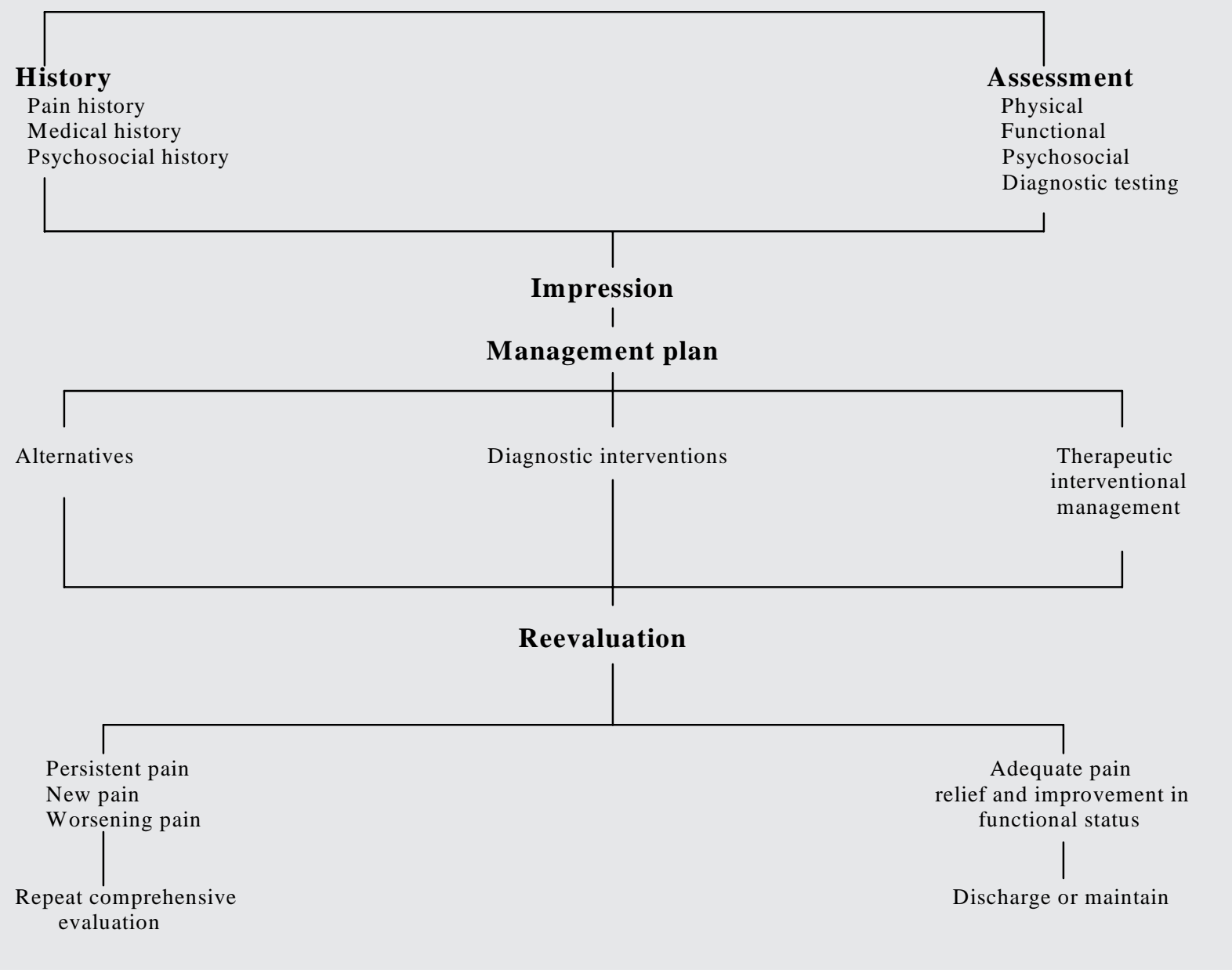

disc fails. In such a study, it was shown that the success of a second operation was $50 \%$, with an additional $20 \%$ considering themselves worse after the surgery (133). With a third procedure, the success rate was $30 \%$ with $25 \%$ considering themselves worse; and after four operations, only a $20 \%$ success rate was achieved, with $45 \%$ of these patients considering themselves worse (133). Hence, if additional costs of repeat surgery are taken into consideration, the cost of lumbar surgery will probably be much higher. Mueller-Schwefe and colleagues (405), in evaluating cost effectiveness of intrathecal therapy for pain secondary to failed back surgery syndrome, compared alternative therapies for achieving a defined outcome, reporting the cost of medical management to be $\$ 85,186$ per 5 years, $\$ 17,037$ per year, and $\$ 1,420$ per month. They also showed that intrathecal morphine delivery resulted in lower cumula- tive 60 -month costs of $\$ 82,893$ per 5 years, $\$ 16,579$ per year, and $\$ 1,382$ per month.

Evaluation of caudal, interlaminar, and transforaminal steroid injections for the management of low back pain revealed surprising results, with cost effectiveness of caudal epidural steroids at $\$ 3,635$ and transforaminal steroids at $\$ 2,927$ per year, whereas interlaminar or lumbar epidural steroids were not shown to be cost effective at a cost of $\$ 6,024$ per year (313). Cost effectiveness of percutaneous nonendoscopic adhesiolysis and hypertonic saline neurolysis, and percutaneous endoscopic adhesiolysis was demonstrated to be $\$ 5,564$ and $\$ 8,127$ respectively for improvement of 1 year of quality of life for patients with chronic low back pain nonresponsive to numerous other modalities of treatment (356). It was $\$ 2,028$ 
Fig. 4. Features of somatic and radicular pain

\begin{tabular}{|c|c|c|}
\hline & Referred somatic pain & Radicular pain \\
\hline Causes & $\begin{array}{l}\text { - Facet joint-mediated pain } \\
\text { - Sacroiliac joint-mediated pain } \\
\text { - Myofascial syndrome }\end{array}$ & $\begin{array}{l}\text { - Disc herniation } \\
\text { - Annular tear } \\
\text { - Spinal stenosis }\end{array}$ \\
\hline \multicolumn{3}{|l|}{ Symptoms } \\
\hline Quality & $\begin{array}{l}\text { - Deep, aching } \\
\text { - Poorly localized } \\
\text { - Back worse than leg } \\
\text { - No paraesthesia } \\
\text { - Covers a wide area } \\
\text { - No radicular or shooting pain }\end{array}$ & $\begin{array}{l}\text { - Sharp, shooting } \\
\text { - Well localized } \\
\text { - Leg worse than back } \\
\text { - Paresthesia present } \\
\text { - Well defined area } \\
\text { - Radicular distribution }\end{array}$ \\
\hline Modification & $\begin{array}{l}\text { - Worse with extension } \\
\text { - Better with flexion } \\
\text { - No radicular pattern }\end{array}$ & $\begin{array}{l}\text { - Worse with flexion } \\
\text { - Better with extension } \\
\text { - Radicular pattern }\end{array}$ \\
\hline Radiation & $\begin{array}{l}\text { - Low back to hip, thigh, groin } \\
\text { - Radiation below knee unusual } \\
\text { - No radicular pattern }\end{array}$ & $\begin{array}{l}\text { - Follows nerve root distribution } \\
\text { - Radiation below knee common } \\
\text { - Radicular and shooting pain }\end{array}$ \\
\hline \multicolumn{3}{|l|}{ Signs } \\
\hline $\begin{array}{l}\text { Sensory alterations } \\
\text { Motor changes }\end{array}$ & $\begin{array}{l}\text { - Uncommon } \\
\text { - Only subjective weakness } \\
\text { - Atrophy is rare }\end{array}$ & $\begin{array}{l}\text { - Probable } \\
\text { - Objective weakness } \\
\text { - Atrophy may be present }\end{array}$ \\
\hline $\begin{array}{l}\text { Reflex changes } \\
\text { Straight leg raises }\end{array}$ & $\begin{array}{l}\text { - None } \\
\text { - Only low back pain } \\
\text { - No root-tension signs }\end{array}$ & $\begin{array}{l}\text { - Commonly expressed but seen occasionally } \\
\text { - Reproduction of leg pain } \\
\text { - Positive root-tension signs }\end{array}$ \\
\hline
\end{tabular}

with nonendoscopic and \$7,020 with endoscopic adhesiolysis in post lumbar laminectomy patients (359). Hence, it appears that neural blockade and other interventional techniques are cost effective if performed properly, as shown in Fig. 2.

\section{CLINICAL ALGORITHM}

The clinical algorithms presented on the following page show an effort to blend conscientious, explicit, and judicious use of the current best evidence in making decisions about the care of individual patients. When this is combined with the clinician's experience and judgment, and patient preferences, it should result in improved outcomes and significantly improved quality of care.

The following criteria should be considered carefully in performing interventional techniques:

1. Complete initial evaluation including history and physical examination.

2. Physiological and functional assessment, as nec- essary and feasible.

3. Definition of indications and medical necessity:

$\checkmark \quad$ Suspected organic problem.

Nonresponsiveness to conservative modalities of treatments except in acute situations such as acute disc herniation, herpes zoster and postherpetic neuralgia, reflex sympathetic dystrophy, and intractable pain secondary to carcinoma. Pain and disability of moderate-to-severe degree.

No evidence of contraindications such as severe spinal stenosis resulting in intraspinal obstruction, infection, or predominantly psychogenic pain.

Responsiveness to prior interventions with improvement in physical and functional status for repeat blocks or other interventions.

Repeating interventions only upon return of pain and deterioration in func- 
tional status.

\section{DIAGNOSTIC BLOCKS}

Diagnostic blockade of a structure with a nerve supply which can generate pain can be performed to test the hypothesis that the target structure is a source of the patient's pain (14). Testing the hypothesis by provoking pain in any structure is an unreliable criterion except in provocative discography (85). However, relief of pain is the essential criterion in almost all structures including analgesic discography in the cervical spine, the only deviation being lumbar discs (14). If the pain is not relieved, the source may be in another structural component of the spine similar to the one tested such as a different facet joint or a different nerve root or some other structure (14). Salient features of somatic and radicular pain are described in Fig. 4. However, one should bear in mind the short comings and pitfalls inherent in the conventional evaluation of spinal pain (Fig. 2).

When the source of pain is more than one structure or multiple levels, it is not expected that all the pain will be relieved. For example, there may be painful facet joints bilaterally at a given segmental level, in which case anesthetizing the left joint should relieve the left side, but not the right side; there may be pain from two consecutive joints on one side, in which case anesthetizing the lower joint alone may relieve only the lower half of the pain; there may be more than one structure involved, such as pain contributed by discs and facet joints or facet joints and nerves (14).

True positive responses are secured by perform-

Figne $5 \mathbf{a}$ A Suggested Algonitlmfor Application of Intenentional Techniques in Consenuative Care of Chrnic Spinal Pain

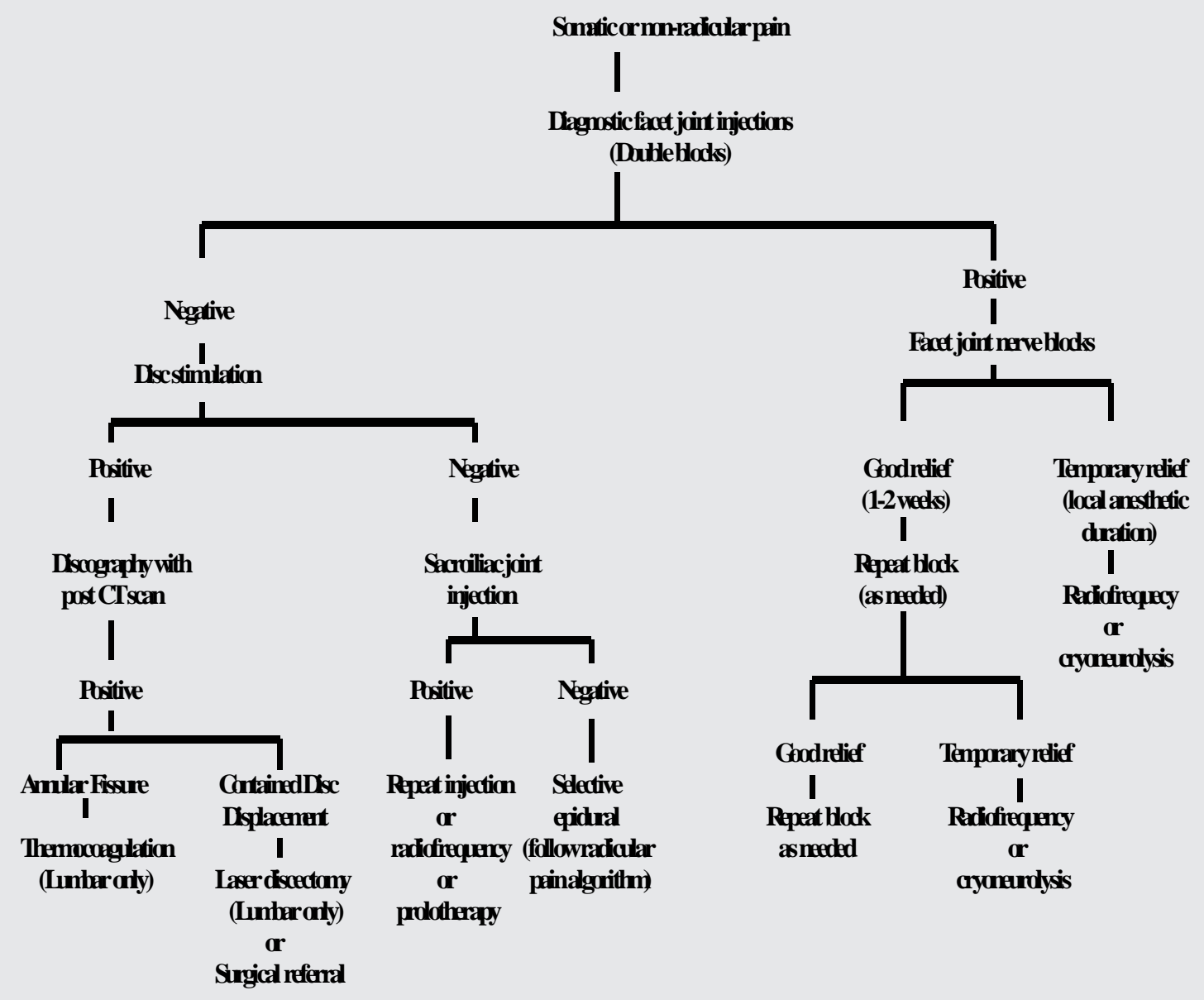


Figure 5b. A suggested Algorithmfor Application of Interventional Techniques in Conservative Care of Chronic Spinal Pain.

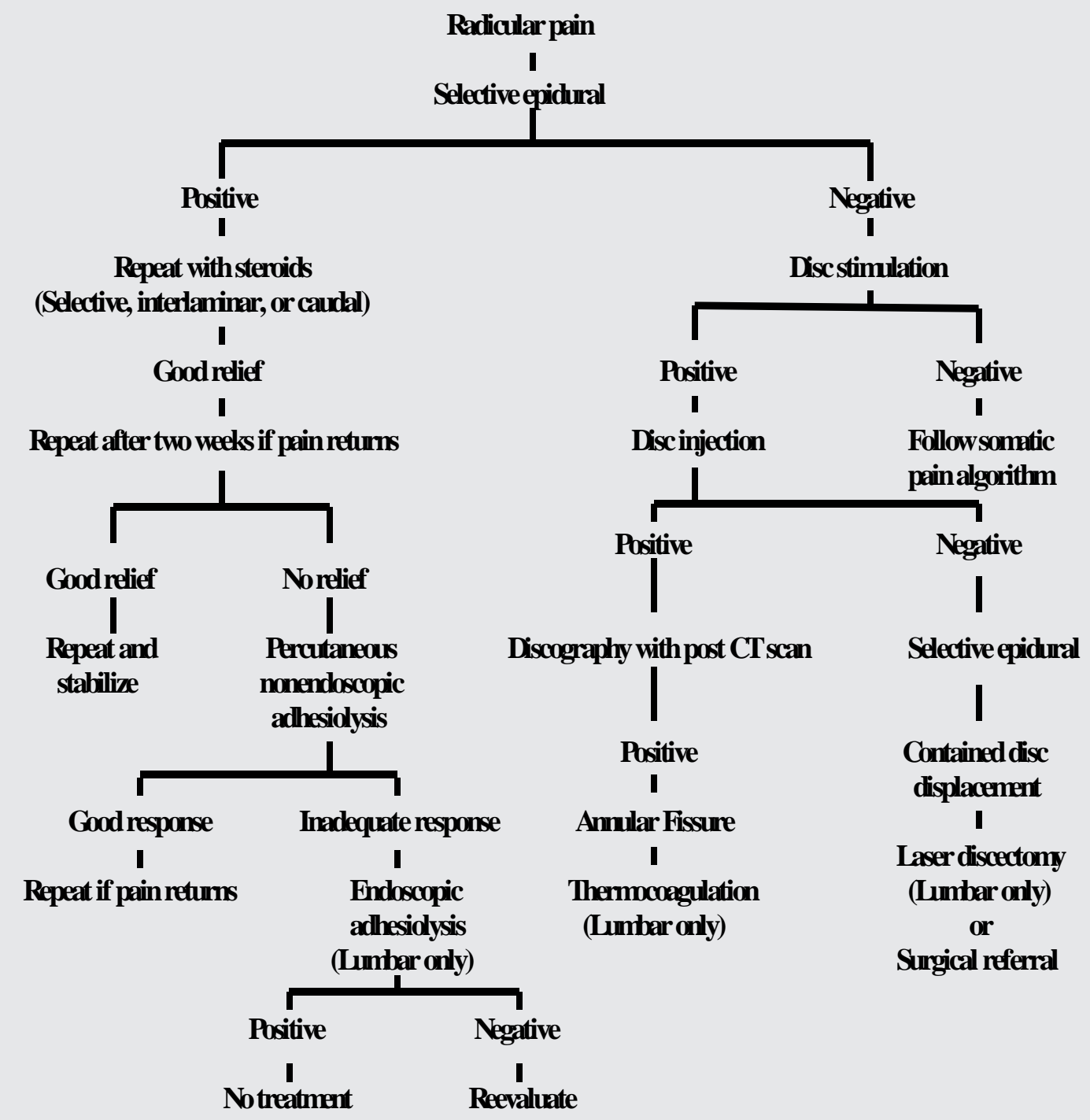

ing controlled blocks. Ideally, this should be in the form of placebo injections of normal saline, but logistic and ethical considerations prohibit the use of normal saline in conventional practice.

In contrast to utilizing placebo blocks, a convenient control is the use of comparative local anesthetic blocks in which on two separate occasions the same structure is anesthetized, but using local anesthetic with different durations of action. However, one of the drawbacks of local anesthetic control is that comparative local anesthetic blocks may not be implementable for intra-articular blocks, for it is not known whether placement of local an- esthetic in a relatively avascular environment such as a joint space affects its expected duration of action. However, these are implemented readily for medial branch blocks and probably for other types of nerve blocks. With medial branch blocks, the use of comparative local anesthetic blocks has been validated and found to be valid against challenge with placebo $(14,407-409)$.

Double blocks with comparative local anesthetics are required, as a diagnosis cannot be rendered reliably on the basis of a single block because false-positive rates are seen in as many as $41 \%$ of patients $(14,111,112$, 407). Thus, controlled blocks are recommended in essen- 
tially every case (14).

It may be essential to combine, in certain circumstances, more than one block. This may include an epidural for the cervical region and facet-joint blocks for the lumbar region; epidural and facet-joint blocks for the same region are indicated when pain generators from both sources have been identified; a sympathetic block and facet-joint block are indicated if there are two different sources of pain or if two different regions are affected in combination with trigger-point injections.

It is recommended that a physician should consider a patient in totality and treat multiple regions of the patient in the same setting, as long as it is safe and feasible. Attempts to treat one particular organ at a different time is not an absolute necessity. However, no more than five procedures (different procedures and/or multiples of one procedure - or total line items of procedures) should be billed in one setting for any of the following: the procedures are performed in different regions or a combination of procedures in one or multiple regions. For treatment of a single region (eg. only lumbosacral spine or cervical spine) a maximum of four (different procedures and/or multiple of one procedure - or total line items of procedures) procedures should be billed.

\section{THERAPEUTIC INTERVENTIONAL TECHNIQUES}

The rationale for therapeutic interventional techniques is based on the fact that, when a particular structure is determined to be the source, long-term relief can be sought by directing therapeutic interventions at that structure. These include facet joints, neural structures, sympathetic ganglion, and peripheral nerves.

The review of the rationale and indications precedes this discussion and is included under neural blockade.

\section{Frequency and Number of Injections or Interventions}

In the diagnostic and stabilization phase, a patient may receive injections at intervals of no sooner than 1 week and preferably 2 weeks for most types of blocks except for blockade in can- cer pain or when a continuous administration of sympathetic blocks is employed.

In the treatment phase (after the stabilization is completed), the frequency of interventional techniques should be 2 months or longer between each injection provided that at least $>50 \%$ relief is obtained for 6 weeks. However, if the neural blockade is applied for different regions, they can be performed at intervals of no sooner than 1 week and preferably 2 weeks for most type of blocks. The therapeutic frequency must remain 2 months for each region. It is further suggested to treat all regions at the same time provided all procedures are performed safely.

In the stabilization phase, the number of injections should be limited to no more than four times per year in cases of all the blocks except sympathetic blocks, in which case six times should be reasonable.

In the maintenance phase, the interventional procedures should be repeated only as necessary judging by the medical necessity criteria and these should be limited to a maximum of six times for local anesthetic and steroid blocks and four times for interventions such as radiofrequency thermoneurolysis, and cryoneurolysis for a period of one year.

For percutaneous non-endoscopic adhesiolysis with a 3-day protocol, 2-3 interventions per year are recommended; with a 1-day protocol, a maximum of 6 times per year is recommended.

For endoscopic adhesiolysis, it is recommended that there be no more than 2-3 interventional procedures per year.

Under unusual circumstances with a recurrent injury, carcinoma, cervicogenic headache, or regional sympathetic dystrophy, blocks may be repeated at intervals of 6 weeks after stabilization in the treatment phase.

\section{Combination of Blocks/Interventions}

It may be essential to combine, in certain circumstances, more than one block. This may include an epidural for the cervical region and facet-joint blocks for the lumbar region; epidural and facet-joint blocks for the same region in case of identification of pain generators from 
both sources; a sympathetic block and facet-joint block if there are two different sources of pain or if two different regions are affected in combination with trigger-point injections. Consequently, blocks also may be combined with other interventional techniques.

\section{Number Per Setting}

It is recommended that a physician should consider a patient in totality and treat multiple regions of the patient in the same setting, as long as it is safe and feasible. Attempts to treat one particular organ at a different time are not an absolute necessity.

However, no more than five procedures (different procedures and/or multiples of one procedure - or total line items or procedures) must be billed in one setting for any of the following: the procedures are performed in different regions or a combination of procedures in one or multiple regions. For treatment of a single region (eg, only lumbosacral spine or cervical spine) a maximum of four procedures (different procedures and/or multiples of one procedure - or total line items or procedures) should be billed.

\section{SPECIFIC INTERVENTIONAL TECHNIQUES}

\section{Diagnostic and Procedure Coding}

The following description of specific interventional techniques includes disease descriptions with ICD9-CM codes (410), and procedure codes of CPT ${ }^{\mathrm{TM}}-1999$ and $2000(411,412)$.

\section{Facet Joint Blocks and Neurolysis}

Facet joints are paired joints extending from the cervical spine through the lumbosacral spine. Due to the functional and structural relationship of atlanto-axial, atlanto-occipital, and sacroiliac joints, the blockade of these joints is also included in facet joints. However, neurolysis is not yet established for the joints other than facet joints per se (eg, not for atlanto-axial joint).

There is no evidence that facet joint-mediated pain, either in the cervical region, thoracic region, or lumbosacral region, can be diagnosed by clinical examination, or by medical imaging.

$\checkmark \quad$ It is generally agreed upon that controlled diag- nostic blocks are the only means available of identifying the source of facet joint-mediated pain. Controlled studies have shown that facet-joint pain contributes to $15 \%$ to $40 \%$ in the lumbar spine and over $50 \%$ in the cervical spine.

Any of the spinal joints can be anesthestized either with intra-articular injections of local anesthetic or by anesthetizing the medial branches of the dorsal rami that innervate the target joint or the nerve supply to atlanto-axial, atlanto-occipital, and sacroiliac joints.

If pain is not relieved, the joint cannot be considered the source of pain and the source may be either another facet joint or some other structure. If the pain is relieved, the joint may be considered to be the source of pain. However, falsepositive responses must be ruled out, which may be seen in almost $40 \%$ of the patients.

* All the patient's pain need not be relieved, for it is possible that a patient may have several sources of pain.

* Comparative local anesthetic blocks, in which on two separate occasions the same joint is anesthetized, but using local anesthetics with different durations of action or placebo blocks.

* Comparative local anesthetic blocks may not be implementable for intra-articular blocks, but are readily implemented if medial branch blocks are used.

* A true positive response confirms that the joint is the source of the pain, with a confidence of $85 \%$.

It is recognized that it may be necessary to provide additional blocks in conjunction with facet-joint blocks such as selective nerve root or selective epidural blocks and disc injections. It is also recognized that multiple levels of facet-joint blocks may be performed in one setting, either in the same region or in multiple regions, more commonly than not.

Facet joint denervation is based on the outcome of a diagnostic facet-joint nerve block, with the patient obtaining sufficient relief for a meaningful period of time, but when pain recurs, a repeat block utilizing a small dose of local anesthetic and steroid does not provide longerlasting relief. This is performed either by injecting neuro- 
lytic substance or by denervation utilizing radiofrequency thermoneurolysis or cryoneurolysis.

If facet joint-mediated pain is present in conjunction with radiculopathy, both ailments should be managed.

Procedure (CPT) Codes:

1999 Codes (411)

- 64442 - Injection, anesthetic agent; paravertebral facet-joint nerve block, lumbar, single level 64443 - Injection, anesthetic agent; paravertebral facet-joint nerve block, lumbar, each additional level

- 64622 - Destruction by neurolytic agent, paravertebral facet-joint nerve, lumbar, single level

- $\quad 64623$ - Destruction by neurolytic agent, paravertebral facet-joint nerve, lumbar, each additional level

2000 Codes (412)

- 64470 - Injection, anesthetic agent and/or steroid, paravertebral facet-joint or facet-joint nerve, cervical or thoracic, single level

64472 - Injection, anesthetic agent and/or steroid, paravertebral facet-joint or facet-joint nerve, cervical or thoracic, each additional level

- 64475 - Injection, anesthetic agent and/or steroid, paravertebral facet joint or facet joint nerve, lumbar or sacral, single level

- 64476 - Injection, anesthetic agent and/or steroid, paravertebral facet-joint or facet-joint nerve, lumbar or sacral, each additional level

- 64626 - Destruction by neurolytic agent, paravertebral facet-joint nerve; cervical or thoracic, single level

- 64627 - Destruction by neurolytic agent, paravertebral facet-joint nerve; cervical or thoracic, each additional level

- $\quad 64622$ - Destruction by neurolytic agent, paravertebral facet-joint nerve; lumbar or sacral, single level

- 64623 - Destruction by neurolytic agent, paravertebral facet-joint nerve; lumbar or sacral, each additional level

- 27096 - Injection procedure for sacroiliac joint, arthrography and/or anesthetic/steroid

- $\quad 73542$ - Radiological examination, sacroiliac joint arthrography, radiological supervision and interpretation

76005 - Fluoroscopic guidance and localization of needle or catheter tip for spine or paraspinous diagnostic or therapeutic injection procedures (epidural, transforaminal epidural, subarachnoid, paravertebral facet joint, paravertebral facet joint nerve or sacroiliac joint), including neurolytic agent destruction

Diagnostic (ICD9) Codes (410)

1. Spondylosis without myelopathy, dorsal arthritis, osteoarthritis, and spondyloarthritis (facet-joint arthropathy) 721.0 cervical, 721.2 thoracic, 721.3 lumbar, 720.2 sacroiliitis, and 721.7 traumatic spondylopathy

2. Post laminectomy syndrome: 722.81 cervical; 722.82 thoracic; 722.83 lumbar

3. Degeneration of intervertebral disc, including narrowing of disc space 722.4 cervical, 722.51 thoracic, 722.52 lumbar

4. Strain 847.0 cervical, 847.1 thoracic, 847.2 lumbar

5. Torticollis 754.1 congenital, 333.83 spasmodic, 347.0, traumatic

6. Spondylolysis 756.11 congenital, 738.4 , acquired

7. Spondylolisthesis 756.12 congenital, 738.4 acquired

\section{Epidural Injections}

Epidural injections are used both for diagnostic and therapeutic purposes. Epidural injections are performed in the cervical region, thoracic region, and lumbosacral region. Epidural injections are performed by various means:

1. Interlaminar (cervical, thoracic, and lumbar)

2. Transforaminal (cervical, thoracic, lumbar, and sacral)

3. Caudal

Procedure (CPT) Codes:

1999 Codes (411)

62275 - Injection of diagnostic or therapeutic anesthetic or antispasmodic substance (including narcotics); epidural, cervical or thoracic, single 62278 - Injection of diagnostic or therapeutic anesthetic or antispasmodic substance (including narcotics); epidural, lumbar or caudal, single 
62279 - Injection of diagnostic or therapeutic anesthetic or antispasmodic substance (including narcotics); epidural, lumbar or caudal, continuous

$\checkmark \quad 62289$ - Injection of substance other than anesthetic, antispasmodic, contrast, or neurolytic solutions; lumbar or caudal (separate procedure)

- $\quad 01996$ - Daily management of epidural or subarachnoid drug administration

$\checkmark \quad 62284$ - Injection procedure for myelography

2000 Codes (412)

62310 - Injection, single (not via indwelling catheter), not including neurolytic substances, with or without contrast (for either localization or epidurography), of diagnostic or therapeutic substance(s) (including anesthetic, antispasmodic, opioid, steroid, other solution), epidural or subarachnoid; cervical or thoracic

62311 - Injection, single (not via indwelling catheter), not including neurolytic substances, with or without contrast (for either localization or epidurography), of diagnostic or therapeutic substance(s) (including anesthetic, antispasmodic, opioid, steroid, other solution), epidural or subarachnoid; lumbar, sacral (caudal)

62318 - Injection, including catheter placement, continuous infusion or intermittent bolus, not including neurolytic substances, with or without contrast (for either localization or epidurography), of diagnostic or therapeutic substance(s) (including anesthetic, antispasmodic, opioid, steroid, other solution), epidural or subarachnoid; cervical or thoracic

62319 - Injection, including catheter placement, continuous infusion or intermittent bolus, not including neurolytic substances, with or without contrast (for either localization or epidurography), of diagnostic or therapeutic substance(s) (including anesthetic, antispasmodic, opioid, steroid, other solution), epidural or subarachnoid; lumbar, sacral (caudal)

- 64479 - Injection, anesthetic agent and/or steroid, transforaminal epidural; cervical or thoracic, single level

64480 - Injection, anesthetic agent and/or steroid, transforaminal epidural; cervical or thoracic, each additional level

- 64483 - Injection, anesthetic agent and/or steroid, transforaminal epidural; lumbar or sacral, single level

64484 - Injection, anesthetic agent and/or steroid, transforaminal epidural; lumbar or sacral, each additional level

72275 - Epidurography, radiological supervision and interpretation

76005 - Fluoroscopic guidance and localization of needle or catheter tip for spine or paraspinous diagnostic or therapeutic injection procedures (epidural, transforaminal epidural, subarachnoid, paravertebral facet joint, paravertebral facet joint nerve or sacroiliac joint), including neurolytic agent destruction

Diagnostic (ICD9) Codes (410)

1. Postlaminectomy syndrome

- $\quad 722.81$ cervical, 722.82 thoracic, 722.83, lumbosacral

2. Disc displacement without myelopathy (disc herniation, radiculitis, disc extrusion, disc protrusion, disc prolapse, discogenic syndrome).

- $\quad 722.0$ cervical, 722.11 thoracic, 722.10 lumbosacral

3. Disc displacement with myelopathy

- $\quad 722.71$ cervical, 722.72 thoracic, 722.73 lumbosacral

4. Degeneration of intervertebral disc (includes narrowing of disc space)

- $\quad 722.4$ cervical, 722.51 thoracic, 722.52 lumbosacral

5. $\quad 721.7$ traumatic spondylopathy

6. Epidural fibrosis

$\checkmark \quad 349.2$ cervical, 349.2 thoracic, 349.2 lumbosacral

7. Radiculitis

- $\quad 723.4$ cervical, 724.4 thoracic, 724.4 lumbosacral

8. Spinal stenosis

- $\quad 723.0$ cervical, 724.04 thoracic, 724.02 lumbosacral

9. Spondylosis with myelopathy (anterior/vertebral artery compression, spondylogenic compression of cord)

- $\quad 721.1$ cervical, 721.41 thoracic, 721.42 lumbosacral

10. Facet arthropathy or spondylosis without myelopathy, dorsal arthritis, osteoarthritis, and spondyloarthritis

- $\quad 721.0$ cervical, 721.2 thoracic, 721.3 lumbosacral

Pain Physician Vol. 3, No. 1, 2000 
11. Strain

- $\quad 847.0$ cervical, 847.1 thoracic, 847.2 lumbosacral

12. Plexus lesions (thoracic-outlet syndrome brachial plexus, lumbar plexus)

353.0 cervical, 353.1 lumbosacral

13. Root lesions (NES) neuritis

353.2 cervical, 353.3 thoracic, 353.4 lumbosacral

14. Closed fracture of spine

- $\quad 805.0$ cervical, 805.2 thoracic, 805.4 lumbar, 805.6 sacral

15. Spina bifida

741.91 cervical, 741.92 thoracic, 741.93 lumbosacral

16. Spina bifida occulta

- $\quad 756.17$ cervical, 756.17 thoracic, 756.17 lumbosacral

17. Congenital spondylolysis

756.11 cervical, 756.11 thoracic, 756.11 lumbosacral

18. Acquired/degenerative spondylolysis or acquired spondylolisthesis

- $\quad 738.4$ cervical,. 738.4 thoracic, 738.4 lumbosacral

19. Congenital spondylolisthesis

756.12 cervical, 756.12 thoracic, 756.12 lumbosacral

20 Rheumatoid arthritis 714.0

21. Coccygodynia 724.79

22. Sciatica 724.3

23. Complex regional pain syndrome (Type I or RSD) 337.20 RSD unspecified, 337.21 RSD upper limb, 337.22 RSD lower limb, 337.29 RSD other unspecified site

24. Complex regional pain syndrome (Type II or causalgia)

- $\quad 355.9$ causalgia, 354.4 causalgia upper limb, 355.71 causalgia lower limb

25. Peripheral neuropathy

356.4 idiopathic, 356.0 hereditary, 357.2 diabetic, 357.5 alcoholic, 357.6 due to drug

26. Limb pain

353.6 phantom limb pain, 997.60 stump pain, 997.61 neuroma of amputation stump, 342.0 hemiplegia - flaccid, 342.1 hemiplegia - spastic

27. Postherpetic neuralgia
053.10 with unspecified nerve system complication

- $\quad 053.13$ postherpetic polyneuropathy

28. Pain syndromes secondary to neoplasm 141.0 239.9

29. Vascular ischemic pain

\section{Percutaneous Lysis of Epidural Adhesions}

Percutaneous nonendoscopic epidural adhesiolysis utilizing a Racz ${ }^{\circledast}$ catheter can be performed in two ways. The original protocol requires epidurography; adhesiolysis; and injection of hyaluronidase, bupivacaine, triamcinolone diacetate, and sodium chloride solution on day 1 and injection of bupivacaine and hypertonic sodium chloride solution on days 2 and 3 . The simplified and modified technique involves a 1-day procedure.

Percutaneous epidural endoscopic adhesiolysis is described as a minimally invasive technique for adhesiolysis and accurate placement of injectate into the epidural space.

\section{Procedure (CPT) Codes}

1999 Codes (411)

62281 - Injection of neurolytic substance (eg, alcohol, phenol, saline solutions); epidural, cervical or thoracic

62282 - Injection of neurolytic substance (eg, alcohol, phenol, saline solutions); epidural, lumbar or caudal

62284 - Injection procedure for myelography and/ or computerized axial tomography, spinal (other than C1-2 and posterior fossa)

01996 - Daily management of epidural or subarachnoid drug administration

64714 - Neuroplasty, major peripheral nerve, lumbar plexus or 64722, decompression; unspecified nerve(s) or

64727 - Internal neurolysis, requiring use of operating microscope

2000 Code (412)

62263 - Percutaneous lysis of epidural adhesions using solution injection (eg, hypertonic saline, enzyme) or mechanical means (eg, spring-wire 
catheter) including radiologic localization (includes contrast when administered)

Diagnostic (ICD9) Codes (410)

1. Postlaminectomy syndrome 722.81 cervical, 722.82 thoracic, 722.83 lumbosacral

2. $\quad$ Epidural fibrosis 349.2

3. Disc displacement with myelopathy

- $\quad 722.71$ cervical, 722.72 thoracic, 722.73 lumbosacral

4. Disc displacement without myelopathy (disc herniation, radiculitis, disc extrusion, disc protrusion, disc prolapse, discogenic syndrome).

722.0 cervical, 722.11 thoracic, 722.10 , lumbosacral

5. Degeneration of intervertebral disc (includes narrowing of disc space)

722.4 cervical, 722.51 thoracic,

722.52 lumbosacral

\section{Sympathetic Blocks and Neurolysis}

Procedure (CPT) Codes $(411,412)$

A. Local anesthetic blocks

1. 64505 sphenopalatine ganglion block

2. 64510 injection, anesthetic agent; stellate ganglion (cervical sympathetic)

3. 64520 injection, anesthetic agent; lumbar or thoracic (paravertebral sympathetic)

4. 64530 injection, anesthetic agent; celiac plexus, with or without radiological monitoring

B. Neurolytic blocks

1. 64680 celiac plexus neurolytic block

2. A physician may use modifier 22 for:

* Sphenopalatine ganglion

* Stellate ganglion

* Thoracic or lumbar paravertebral sympathetic

Diagnostic (ICD9) Codes (410)

1. Complex regional pain syndrome type I (RSD), type II (causalgia)

* $\quad 337.20$ RSD unspecified, 337.21 RSD

upper limb, 337.22 RSD lower limb,
337.29 RSD other unspecified site

* $\quad 355.9$ causalgia, 354.4 causalgia upper limb, 355.71 causalgia lower limb

2. Peripheral neuropathy

* $\quad 356.4$ idiopathic, 356.0 hereditary, 357.2 diabetic, 357.5 alcoholic, 357.6 due to

3. Limb pain drug

* $\quad 353.6$ phantom limb pain, 997.60 stump pain, 997.61 neuroma of amputation stump, 342.0 hemiplegia - flaccid, 342.1 hemiplegia - spastic

4. Plexus lesions

* $\quad 353.0$ thoracic outlet syndrome, 353.1 lumbar plexus lesions

Postherpetic neuralgia

* $\quad 053.10$ with unspecified nerve system complication, 053.11 geniculate herpes zoster, 053.12 postherpetic trigeminal neuralgia, 053.13 postherpetic polyneuropathy, 053.19 other, 053.12 herpes zoster dermatitis of upper eyelid, 053.21 herpes zoster keratoconjunctivitis, 053.22 herpes zoster iridocyclitis, 053.29 other ophthalmic complications

6. Pain syndromes secondary to neoplasm 141.0 239.9

7. Vascular ischemic pain

8. Headache

* $\quad 346.01$ intractable migraine with aura, 346.11 intractable migraine without aura, 346.21 intractable cluster, 346.20 nonintractable cluster, 346.9 unspecified migraine

\section{Intercostal Nerve Blocks and Neurolysis}

Procedure CPT Codes $(411,412)$

64420 - Introduction / injection of anesthetic agent (nerve block), diagnostic or therapeutic, intercostal nerve, single.

64421 - Introduction / injection of anesthetic agent (nerve block), diagnostic or therapeutic, intercostal nerve, multiple.

64620 - Destruction by neurolytic agent; intercostal nerve.

64620-51 - Destruction by neurolytic agent, additional levels

Diagnostic (ICD-9) Codes (410) 
1. $\quad 353.3$ thoracic root lesions, not elsewhere classified (intercostal neuritis)

2. $\quad 353.8$ other nerve root and plexus disorders

3 . $\quad 353.9$ unspecified nerve root and plexus disorder

4. $\quad 053.10$ herpes zoster with unspecified nervous system complication

5. $\quad 053.13$ post herpetic polyneuropathy

6. $\quad 114.02-239.9$ pain syndromes secondary to neoplasm

\section{Trigeminal Nerve Block(s)}

Trigeminal nerve block with local anesthetic and steroid is utilized in managing pain or trigeminal neuralgia or cancer pain when pharmacological measures fail.

Procedure (CPT) Codes $(411,412)$

$\checkmark \quad 64400$ injection, anesthetic agent; trigeminal nerve, any division or branch.

- 64600 destruction by neurolytic agent, trigeminal nerve; supraorbital, infraorbital, mental, or inferior alveolar branch

- 64605 destruction by neurolytic agent, trigeminal nerve; second and third branches at foramen ovale

- 64610 destruction by neurolytic agent, trigeminal nerve; second and third division branches at foramen ovale under radiological monitoring

Diagnostic (ICD9) Codes (410)

1. $\quad 350.1$ trigeminal neuralgia

2. $\quad 350.2$ atypical facial pain

3. $\quad 350.8$ trigeminal neuralgia, specified

4. $\quad 350.9$ trigeminal neuralgia, unspecified

5. 053.12 postherpetic trigeminal neuralgia

\section{Discography and Annuloplasty}

Even though riddled with controversy, disc stimulation and injections are used quite frequently for the purposes of diagnosis of discogenic syndrome, as well as prior to surgical intervention such as fusion. Intradiscal thermocoagulation with a catheter was introduced in 1998. Stringent standards of practice have been established to ensure that the results of discography are not polluted by false-positive responses.

Procedure (CPT) Codes $(411,412)$
62290 injection procedure for discography, each level; lumbar

62291 injection procedure for discography, each level; cervical or thoracic

No CPT codes are available for disc thermal annuloplasty. The following code is utilized with revised description:

62287 aspiration or decompression procedure, percutaneous, of nucleus pulposus of intervertebral disk, any method, single or multiple levels, lumbar (eg, manual or automated percutaneous diskectomy, percutaneous laser diskectomy)

Diagnostic (ICD9) Codes (410)

1. Disc displacement without myelopathy (disc herniation, radiculitis, extrusion, protrusion, prolapse, discogenic syndrome)

- $\quad 722.0$ cervical, 722.11 thoracic, 722.10 lumbosacral

2. Degeneration of intervertebral disc including narrowing of disc space

- 722.4 cervical, 722.51 , thoracic, 722.52 lumbosacral

\section{Trigger-Point Injections}

Myofascial trigger points are self-sustaining hyperirritative foci that may occur in any skeletal muscle in response to strain produced by acute or chronic overload.

Procedure (CPT) Codes $(411,412)$

1. 20550, injection, tendon sheath, ligament, trigger points, or ganglion cyst.

Diagnostic (ICD-9) Codes (410)

1. $\quad 729.1$ myalgia and myositis, unspecified

2. $\quad 729.0$ rheumatism, unspecified and fibrocysitis

\section{REFERENCES}

1. Committee to Advise the Public Health Service on Clinical Practice Guidelines, Institute of Medicine. Field MJ, Lohr KN (eds). Clinical practice guidelines. Directions of a new program. Washington, DC; Na- 
tional Academy Press; 1990.

2. Manchikanti L. The role of neural blockade in the management of chronic low back pain. Pain Digest 1999; 9:166-181.

3. Manchikanti L. Neural blockade in cervical pain syndromes. Pain Physician, 1999; 2:65-84.

4. Bogduk N, Christophidis N, Cherry D et al. Epidural use of steroids in the management of back pain. Report of working party on epidural use of steroids in the management of back pain. National Health and Medical Research Council. Canberra, Commonwealth of Australia, 1994: pp 1-76.

5. Bogduk N. Epidural steroids for low back pain and sciatica. Pain Digest 1999; 9:226-227.

6. Nash TP. Current guidelines in the use of epidural steroids in the United Kingdom. Pain Digest 1999; 9:231232.

7. Abram SE. Current guidelines in the use of epidural steroids in the United States of America. Pain Digest 1999; 9:233-234.

8. $\quad$ Raj PP. Epidural steroid injections. Pain Digest 1999; 9:235-240.

9. Koes BW, Scholten R, Mens JMA et al. Epidural steroid injections for low back pain and sciatica. An updated systematic review of randomized clinical trials. Pain Digest 1999; 9:241-247.

10. Van Zundert J, Plaghki L, Adriaensen H. Conclusions: Value of epidural corticosteroid injections in low back pain and sciatica. Pain Digest 1999; 9:248-251.

11. Watts RW, Silagy CA. A meta-analysis on the efficacy of epidural corticosteroids in the treatment of sciatica. Anaesth Intens Care 1995; 23:564-569.

12. Koes BW, Scholten RJPM, Mens JMA et al. Efficacy of epidural steroid injections for low back pain and sciatica: A systematic review of randomized clinical trials. Pain 1995;63:279-288.

13. Manchikanti L. Facet joint pain and the role of neural blockade in its management. Current Reviews of Pain 1999; 3:348-358.

14. Bogduk N. International spinal injection society guidelines for the performance of spinal injection procedures. Part 1: Zygapophyseal joint blocks. Clin J Pain 1997;13:285-302.

15. Turk DC. Here we go again. Outcomes, outcomes, outcomes. Clin J Pain 1999; 15:241-243.

16. Turk DC, Okifuji A. Treatment of chronic pain patients. Clinical outcomes, cost-effectiveness, and costbenefits of multidisciplinary pain centers. Crit Rev Phys Rehabil Med 1998; 10:181-208.

17. Van Tulder MW, Koes BW, Bouter LM. Conservative treatment of acute chronic nonspecific low back pain. A systematic review of randomized controlled trials of the most common interventions. Spine 1997; 22:2128-2156.

18. Bigos SJ, Boyer OR, Braen GR et al. Acute low back problems in adults. Clinical Practice Guideline Num- ber 4. AHCPR Publication No. 95-0642. Rockville, MD, Agency for Health Care Policy and Research, Public Health Service, US Department of Health and Human Services, December 1994.

19. Turner JA, Loeser JD, Bell KG. Spinal cord stimulation for chronic low back pain. A systematic literature synthesis. Neurosurgery 1995; 37:1088-1098.

20. Weinstein JN. The tortoise and the hare. Is there a place in spine surgery for randomized trials? Spine 1999; 23:2548-2549.

21. Winter RB. The prospective, randomized, controlled clinical trial in spine surgery. Fact or fiction? Spine 1999; 23:2550-2552.

22. Carey TS. Randomized controlled trials in surgery. An essential component of scientific progress. Spine 1999; 23:2553-2555.

23. Fairbank J. Randomized controlled trials in the surgical management of spinal problems. Spine 1999; 23:2556-2563.

24. Tosteson TD. Point of view. Spine 1999; 24:25622563.

25. Gureje O, Von Korff M, Simon GE et al. Persistent pain and well being: A World Health Organization Study in Primary Care. JAMA 1998;280:147-151.

26. Cousins MJ. Pain: The past, present, and future of anesthesiology? The E.A. Rovenstine Memorial Lecture. Anesthesiology 1999; 91:538-551.

27. Hoffmann DE. Pain management and palliative care in the era of managed care: Issue for health insurers. $J$ Law, Med \& Ethics 1998;26:267-289.

28. Helme RD, Gibson SJ. Pain in older people. In: Crombie IK, Croft PR, Linton SJ et al (eds). Epidemiology of pain. IASP Press; Seattle, 1999; pp 103-112.

29. Bressler HB, Keyes WJ, Rochon PA et al. The prevalence of low back pain in the elderly. A systemic review of the literature. Spine 1999; 24:1813-1819.

30. Pahor M, Guralnik JM, Wan JY. Lower body osteoarticular pain and dose of analgesic medications in older disabled women: The Women's Health and Aging Study. Am J Public Health 1999; 89:930-934.

31. Bonica JJ. Definitions and taxonomy of pain. In: Bonica JJ, Loessor JD, Chapman CR et al (eds). The management of pain, Second Edition. Philadelphia, Lea \& Febiger, vol 1, 1990: PP18-27.

32. Pain. In: Guides to the evaluation of permanent impairment. American Medical Association: Fourth Edition. Chicago, 1993: PP303-311.

33. Merskey H, Bogduk N. Classification of chronic pain: Descriptions of chronic pain syndromes and definitions of pain terms. Second Edition. Seattle, IASP Press, 1994.

34. Corran TM, Farrell MJ, Helme RD et al. The classification of patients with chronic pain: Age as a contributing factor. Clin J Pain 1997; 13:207-214.

35. Hendler NH, Bergson C, Morrison C. Overlooked physical diagnoses in chronic pain patients involved 
in litigation. Part 2. Psychosomatics 1996; 37:509517.

36. Hendler NH, Kolodny AL. Using medication wisely in chronic pain. Patient Care 1992; May 15: 125.

37. Leigh JP, Markowitz S, Fahs M et al. Occupational injury and illness in the United States. Estimates of costs, morbidity, and mortality. Arch Intern Med 1997; 157:1557-1568.

38. Spitzer WO, Leblanc FE, Dupuis M (eds). Quebec Task Force on Spinal Disorders. Scientific approach to the assessment and management of activity-related spinal disorders: A monograph for clinicians. Spine 1987;(suppl)12:1-59.

39. Lawrence RC, Helmick CG, Arnett FC. Estimates of the prevalence of arthritis and selected musculoskeletal disorders in the United States. Arthritis \& Rheumatism 1998; 41:778-799.

40. Deyo RA, Tsui-Wu YJ. Descriptive epidemiology of low back pain and its related medical care in the United States. Spine 1987; 12:264-268.

41. Leboeuf-Yde C, Klougart N, Lauritzen T. How common is low back pain in the Nordic population? Spine 1996;21:1518-1526.

42. Reisbord LS, Greenland S. Factors associated with selfreported back pain prevalence: A population-based study. J Chronic Dis 1985;38:691-702.

43. Frymoyer JW, Pope MH, Clements JG, et al: Risk factors in low-back pain: An epidemiological survey. $J$ Bone Joint Surg Am 1983;65:218-218.

44. Cassidy D, Carroll L, Cote P: The Saskatchewan Health and Back Pain Survey. Spine 1998;23:1860-1867.

45. Carey TS, Evans AT, Hadler NM, et al. Acute severe low back pain: A population based survey of prevalence and care-seeking. Spine 1996;21:339-344.

46. Salimine JJ, Erkintalo (Tetti) M, Laine M et al. Low back pain in the young: A prospective three-year follow-up study of subjects with and without low back pain. Spine 1995;20:2101-2107.

47. Davis H. Increasing rates of cervical and lumbar spine surgery in the United States, 1979-1990. Spine 1994;19:1117-1124.

48. Papageorgiou AC, Croft PR, Ferry S et al. Estimating the prevalence of low back pain in the general population: Evidence from the South Manchester Back Pain Survey. Spine 1995;20:1889-1894.

49. Bovim G, Schrader H, Sand T. Neck pain in the general population. Spine 1994;12:1307-1309.

50. Spitzer WO, Skovron ML, Salmi LR et al. Scientific monography of the Quebec Task Force on WhiplashAssociated Disorders: Redefining "whiplash" and it management. Spine 1995;20 (Suppl):1-73.

51. Nilsson. N. The prevalence of cervicogenic headache in a random population sample of 20-59 year olds. Spine 1995;20:1884-1888

52. Lord SM, Barnsley L, Wallis BJ et al. Third occipital nerve headache. A prevalence study. J Neurol
Neurosurg Psychiatry 1994;57:1187-1190..

53. Rasmussen BK, Jensen R, Schroll M, et al. Epidemiology of headache in a general population - A prevalence study. J Clin Epidemiol 1991;44:1147-1157.

54. Van Kleef M, Barendse GAM, Dingemans WAAM et al. Effects of producing a radiofrequency lesion adjacent to the dorsal root ganglion in patients with thoracic segmental pain. Clin J of Pain 1995; 11:325332.

55. Portenoy RK. Cancer pain: Epidemiology and syndromes. Cancer 1989; 63:2298.

56. Van Den Hoogen HJM, Koes BW, Deville W et al. The prognosis of low back pain in general practice. Spine 1997;22:1515-1521.

57. Croft PR, Macfarlane GJ, Papageorgiou AC et al. Outcome of low back pain in general practice: A prospective study. Brit Med J 1998;316:1356-1359.

58. Carey TS, Garrett JM, Jackman A et al. Recurrence and care seeking after acute back pain. Results of a long-term follow-up study. Medical Care 1999; 37:157-164.

59. Burton AK, Tillotson KM, Main CJ et al. Psychosocial predictors of outcome in acute and subchronic low back trouble. Spine 1995; 20:722-728.

60. Burton AK, et al. Four-year follow-up of low back pain in patients in primary care. Third International Forum for Primary Care Research on Low Back Pain, Manchester, UK, 1998.

61. Thomas E, Silman AJ, Croft PR et al. Predicting who develops chronic low back pain in primary care. A prospective study. Brit Med J 1999; 318:1662-1667.

62. Kirkaldy-Wills WH, Wedge JH, Yong-Hing K et al. Pathology and pathogenesis of lumbar spondylosis and stenosis. Spine 1978;3:319-327.

63. Handel JA, Knap J, Poletti S. The structural degenerative cascade. The cervical spine. In: White $\mathrm{AH}$, Schofferaian, JA (eds). Spine care. Diagnosis and conservative treatment. St. Louis, Mosby. 1995: vol. 1, pp16-23.

64. Bogduk N. The innervation of the lumbar spine. Spine 1983;8:286-293.

65. Mixter WJ, Barr JS. Rupture of the intervertebral disc with involvement of the spinal canal. N Eng J Med 1934;211:210-215.

66. Semmes RE, Murphey MF. The syndrome of unilateral rupture of the sixth cervical intervertebral disc with compression of the seventh cervical nerve root. A report of four cases with symptoms simulating coronary disease. JAMA 1943;121:1209.

67. Crock HV. Isolated lumbar disc $\mathrm{r}$ esorption as a cause of nerve root canal stenosis. Clin Orthop 1976;115:109115.

68. McCarron RF, Wimpee MW, Hudkins PG et al. The inflammatory effects of nucleus pulposus: A possible element in the pathogenesis of low back pain. Spine 1987 ; $12: 760-764$. 
69. Saal JS, Franson RC, Dobrow R et al. High levels of inflammatory phospholipase A2 activity in lumbar disc herniations. Spine 1990; 15:674-678.

70. Kellgren JH. The anatomical source of back pain. Rheumatol Rehab 1977; 16:3-12.

71. Hirsch D, Inglemark B, Miller M. The anatomical basis for low back pain. Acta Orthop Scand 1963;33:1.

72. Mooney V, Robertson J. The facet syndrome. Clin Orthop 1976;115:149-156.

73. McCall IW, Park WM, O'Brien JP. Induced pain referral from posterior elements in normal subjects. Spine 1979;4:441-446.

74. Marks R. Distribution of pain provoked from lumbar facet joints and related structures during diagnostic spinal infiltration. Pain 1989;39:37-40.

75. Fukui S, Ohseto K, Shiotani M et al. Distribution of referral pain from the lumbar zygapophyseal joints and dorsal rami. Clin J Pain 1997;13:303-307.

76. Fortin J, Aprill CN, Ponthieux B et al. Sacroiliac joints: Pain referral maps upon applying a new injection/arthrography technique. Part II: Clinical evaluation. Spine 1994;19:1483-1489.

77. Schwarzer AC, Aprill CN, Bogduk M. The sacroiliac joint in chronic low back pain. Spine 1995;20:31-37.

78. Bogduk N, Marsland A. The cervical zygapophyseal joints as a source of neck pain. Spine 1988;13:610617.

79. Fukui S, Ohseto K, Shiotani M et al. Referred pain distribution of the cervical zygapophyseal joints and cervical dorsal rami. Pain 1996;68:79-83.

80. Dreyfuss P, Tibiletti C, Dreyer SJ. Thoracic zygapophyseal joint pain patterns: A study in normal volunteers. Spine 1994; 19:807-811.

81. Suseki K, Takahashi Y, Takahashi K et al. Innervation of the lumbar facet joints. Spine 1997;22:477-485.

82. Bogduk N, Wilson AS, Tynan W. The human lumbar dorsal rami. J Anat 1982;134:383-397.

83. Bogduk N. The clinical anatomy of the cervical dorsal rami. Spine 1982;7:35-45.

84. Schwarzer AC, Aprill CN, Derby R et al. Clinical features of patients with pain stemming from the lumbar zygapophysial joints. Is the lumbar facet syndrome a clinical entity? Spine 1994;19:1132-1137.

85. Schwarzer AC, Derby R, Aprill CN et al. The value of the provocation response in lumbar zygapophysial joint injections. Clin J Pain 1994; 10:309-313.

86. Buckwalter JA. Aging and degeneration of the human intervertebral disk. Spine 1995;20:1307-1314.

87. Hirsch C, Schajowicz F, Galante J. Structural changes in the cervical spine. Acta Orth Scand 1967;109:6872.

88. Lees F, Turner JWA. Natural history and prognosis of cervical spondylosis. Br Med J 1963;2:1607-1610.

89. Lestini WF, Wiesel SW. The pathogenesis of cervical spondylosis. Clin Orthop 1989;239:69-93.

90. Ono K, Ota H, Tada K et al. Cervical myelopathy sec- ondary to multiple spondylotic protrusions: A clinicopathologic study. Spine 1977;2:109-125.

91. Crock HV. A reappraisal of intervertebral disc lesions. Med J Aust 1970;1:983-989.

92. Schwarzer AC, Aprill CN, Derby R et al. The prevalence and clinical features of internal disc disruption in patients with chronic low back pain. Spine 1995;20:1878-1883.

93. Dreyfuss P, Michaelsen M, Fletcher D. Atlanto-occipital and lateral atlanto-axial joint pain patterns. Spine 1994;19:1125-1131.

94. Schwarzer AC, Wang S, Laurent R et al. The role of the zygapophysial joint in chronic low back pain. Aust N Z J Med 1992;22:185.

95. Schwarzer AC, Derby R, Aprill CN et al. Pain from the lumbar zygapophysial joints: A test of two models. J Spinal Disord 1994;7:331-336.

96. Deyo RA. Fads in the treatment of low back pain. $N$ Engl J Med 1991; 325:1039-1040.

97. Saal JA. Natural history and non-operative treatment of lumbar disc herniation. Spine 1996;21:25-35.

98. Thelander U. Fagerlung M., Friberg S et al. Straight leg raising test vs radiologic size, shape, and position of lumbar disc herniations. Spine 1992;17:395-389.

99. Jackson RP, Jacobs RR, Montesano PX. Facet joint injection in low back pain. A prospective study. Spine 1988;13:966-971.

100. Barnsley L, Lord S, Bogduk N. Whiplash injury. Pain 1994;58:238-307.

101. Simons DG. Myofascial trigger points, a possible explanation. Pain 1988; 69:207-212.

102. Deyo RA, Rainville J, Kent DL. What can the history and physical examination tell us about low back pain? JAMA 1992; 268:760-765.

103. Waddell G, Turk DC. Clinical assessment of low back pain. In: Turk DC, Melzack R (eds). Handbook of pain assessment. First Edition. New York, The Guilford Press, 1992;15-36.

104. Haldeman S. Failure of the pathological model to predict back pain. Spine 1990; 15:718-732.

105. Schwarzer AC, Scott AM, Wang SC et al. The role of bone scintigraphy in chronic low back pain: A comparison of SPECT and planar images and zygapophysial joint injection. Aust NZJ Med 1992;22:185.

106. Schwarzer AC, Wang SC, O'Driscoll D et al. The ability of computed tomography to identify a painful zygapophysial joint in patients with chronic low back pain. Spine 1995;20:907-912.

107. Dreyfuss P, Michaelsen M, Pauza K et al. The value of medical history and physical examination in diagnosing sacroiliac joint pain. Spine 1996;21:2594-2602.

108. Kuslich SD, Ulstrom CL, Michael CJ. The tissue origin of low back pain and sciatica: A report of pain response to tissue stimulation during operation on the lumbar spine using local anesthesia. Orthop Clin 
North Am 1991;22:181-187.

109. Bogduk N, Aprill C. On the nature of neck pain, discography, and cervical zygapophyseal joint blocks. Pain 1993;54:213-217.

110. Schwarzer AC, Aprill CN, Derby R et al. The relative contributions of the disc and zygapophyseal joint in chronic low back pain. Spine 1994;19:801-806.

111. Manchikanti L, Pampati VS, Fellows B et al. Prevalence of lumbar facet joint pain in chronic low back pain. Pain Physician 1999; 2:59-64.

112. Manchikanti L, Pampati VS, Bakhit CE et al. The diagnostic validity and therapeutic value of lumbar facet joint nerve blocks with or without adjuvant agents. Current Review of Pain 2000; in press.

113. Mironer YE, Somerville JJ. Protocol for diagnosis and treatment of facet joint pain syndrome. A modified three-step approach. Pain Digest 1999; 9:188-190.

114. Bogduk N, Marsland A. On the concept of third occipital headache. J Neurol Neurosurg Psychiatry 1986;49:775-780.

115. Dwyer A, Aprill C, Bogduk N. Cervical zygapophyseal joint pain patterns: A study in normal volunteers. Spine 1990;6:453-457.

116. Aprill C, Dwyer A, Bogduk N. The prevalence of cervical zygapophyseal joint pain patterns II: A clinical evaluation. Spine 1990;6:458-461.

117. Dreyfuss P, Tibiletti C, Dreyer S et al. Thoracic zygapophyseal joint pain: a review and description of an intra-articular block techniques. Pain Digest 1994; 4:46-54

118. Schwarzer AC, Wang S, Bogduk N et al. Prevalence and clinical features of lumbar zygapophysial joint pain: a study in an Australian population with chronic low back pain. Am Rheum Dis 1995;54:100-106.

119. Barnsley L, Lord SM, Wallis BJ et al. The prevalence of chronic cervical zygapophyseal joint pain after whiplash. Spine 1995;20:20-26.

120. Lord SM, Barnsley L, Wallis BJ et al. Chronic cervical zygapophysial joint pain with whiplash: A placebocontrolled prevalence study. Spine 1996;21:17371745.

121. Weber H. The natural history of disc herniations and the influence of intervention. Spine 1994;19:22342238.

122. Spangfort EV. The lumbar disc herniation. A computer aided analysis of 2504 operations. Acta Orthop Scand (Suppl) 1972; 142:1-95.

123. Michelsen JJ, Mixter WJ. Pain and disability of shoulder and arm due to herniation of the nucleus pulposus of cervical intervertebral discs. $N$ Engl J Med 1944;231:279.

124. Carette S, Lecaire R, Marcoux S et al. Epidural corticosteroid injections for sciatica due to herniated nucleus pulposus. N Engl J Med 1997;336:1634-1640.

125. Ohnmeiss D, Vanharanta H, Ekholm J. Degree of disc disruption and lower extremity pain. Spine
1997;22:1600-1605.

126. Kayama S, Konno S, Olmarker K et al. Incision of the annulus fibrosus induces nerve root morphologic, vascular, and functional changes. Spine 1996;21:25392543.

127. Chaoyang C, Cavanaugh JM, Ozaktay C et al. Effects of phospholipase A2 on lumbar nerve root structure and function. Spine 1997;22:1057-1064.

128. Wilkinson HA. Introduction: Etiology, diagnosis, and therapy. In: The failed back syndrome. Etiology and therapy. Second Edition. New York, Springer-Verlag, 1992;pp1-3.

129. Wilkinson HA. The role of improper surgery in the etiology of the failed back syndrome. In: The failed back syndrome. Etiology and therapy. Second Edition. New York, Springer-Verlag, 1992;pp4-12.

130. Law JD, Lehman RAW, Kirch WM. Reoperation after lumbar intervertebral disc surgery. J Neurosurg 1978;48:259-263.

131. Biondi J, Greenberg BJ. Redecompression and fusion in failed back syndrome patients. J Spinal Disord 1990; 3:362-369.

132. Turner JA, Ersek M, Herron L et al. Surgery for lumbar spinal stenosis, attempted meta-analysis of the literature. Spine 1992;17:1-7.

133. Waddell G, Kummel EG, Lotto WN et al. Failed lumbar disc surgery and repeat surgery following industrial injury. J Bone Joint Surg (Am) 1979;61:201-207.

134. Ross JS, Robertson JT, Frederickson RCA et al. Association between peridural scar and recurrent radicular pain after lumbar discectomy: Magnetic resonance evaluation. Neurosurgery 1996;38:855-863.

135. Fritsch EW, Heisel J, Rupp S. The failed back surgery syndrome. Reasons, intraoperative findings, and longterm results: A report of 182 operative treatments. Spine 1996;21:626-633.

136. Parke WW, Watanable R. Adhesions of the ventral lumbar dura. Adjunct source of discogenic pain? Spine 1990; 15:300-303.

137. Quiles M, Marchisello PJ, Tsairis P. Lumbar adhesive arachnoiditis: Ethological and pathological aspects. Spine 1978; 3:45-50.

138. Benoist M, Ficat C, Baraf P, et al. Post operative lumbar epiduroarachnoiditis: Diagnostic and therapeutic aspects. Spine 1980; 5:432-436.

139. Fager CA, Freidberg SR. Analysis of failures and poor results of lumbar spine surgery. Spine 1980; 5:87-94.

140. Hanley EN, Shapiro DE. The development of low back pain after excision of a lumbar disc. J Bone Joint Surg 1989; 71A:719-721.

141. Frymoyer JW. Magnitude of the problem. In: Weinstein J, Weisel SW (eds). The lumbar spine. WB Saunders, Philadelphia. 1990; pp 32-38.

142. LaRocca H. Failed lumbar surgery. Principles of management. In: Weinstein J, Wiesel S (eds). The lumbar spine. Philadelphia, WB Saunders Company, 1990; 
pp 872-881.

143. Rutkow IM. Orthopaedic operations in the United States, 1979-1983. J Bone Joint Surg 1986; 68A: 716719.

144. Hanley EN Jr. The cost of surgical intervention for lumbar disc herniation. In: Weinstein JN (ed). Clinical efficacy and outcome in the diagnosis and treatment of low back pain. New York, Raven Press. 1992; pp 125-133.

145. Burton CV. Causes of failure of surgery on the lumbar spine: Ten-year follow up. Mt Sinai J Med 1991; 58:183-187.

146. Burton CV, Kirkaldy-Nillis WH, Yong-Hing K et al. Causes of failure of surgery on the lumbar spine. Clin Orthop 1981; 157:191-199.

147. North RB, Campbell JN, James CS et al. Failed back surgery syndrome: 5 year follow-up in 102 patients undergoing repeated operation. Neurosurgery 1991; 28:685-691.

148. Saal JS, Saal JA, Yurth EF. Nonoperative management of herniated cervical intervertebral disc with radiculopathy. Spine 1996;21:1877-1883.

149. Gibson JNA, Grant IC, Waddell G. The Cochrane review of surgery for lumbar disc prolapse and degenerative lumbar spondylosis. Spine 1999; 24:1820-1832.

150. Keller RB, Atlas SJ, Soule DN et al. Relationship between rates and outcomes of operative treatment for lumbar disc herniation and spinal stenosis. J Bone Joint Surg 1999; 81A(6):752-762.

151. Porchet F, Vader JP, Larequi-Lauber T et al. The assessment of appropriate indications for laminectomy. J Bone Joint Surg 1999; 81B(62) 234-239.

152. Wolfe F, Simons DG, Fricton J et al. The fibromyalgia and myofascial pain syndromes. A preliminary study of tender point and trigger points in persons with fibromyalgia pain and no disease. J. Rheumatol 1992;19:944-951.

153. Bogduk N, Simons DG. Neck pain: Joint pain or trigger points. In: H Vaeroy and J Merskey (eds). Progress in fibromyalgia and myofascial pain. Amsterdam , Elsevier, 1993;pp267-273.

154. Bogduk N. Musculoskeletal pain: toward precision diagnosis. Progress in pain research and management. In: Jensen TS, Turner JA, Wiesenfeld-Hallin Z (eds). Proceedings of the 8th World Congress on Pain, Seattle, IASP Press, 1997;pp507-525.

155. Simmons DQ, Travell JG. The myofascial genesis of pain. Postgrad Med 1952;11:425-434.

156. Travell J. Myofascial trigger points. Clinical view. In: Bonica JJ, Able-Fessardi D (eds). Advances in pain research and therapy. New York, Raven Press, 1976, vol 1, pp 919-926.

157. Skootsky SA, Jaeger B, Oye RK. Prevalence of myofascial pain in general internal medicine practice. West J Med 1989;151:157-160.

158. Cathelin F. Mode d'action de a cocaine injete daus l'escapte epidural par le procede du canal sacre. Comptes Rendies des Senaces de la Societe de Biologic et de ses Filliales, 1901;43:487.

159. Pasquier NM, Leri D. Injection intra-et extradurales de cocaine a dose minime daus le traitment de la sciatique. Bull Gen Ther 1901; 142:196.

160. Sicard MA. Les injections medicamenteuse extraduraqles per voie saracoccygiene. Comptes Renues des Senances de la Societe de Biolgie et de ses Filliales, 1901; 53:396.

161. Caussade G, Queste P. Traitement de al neuralgie sciatique par la mèthode de Sicard. Résultats favorables même dans les cas chroniues par la cocaïne à doses élevées et répétées à intervalles raproches. Bull Soc Med Hosp Paris 1909;28:865.

162. Pages E. Anesthesia metamerica. Rev Sanid Mil Madr 1921; 11:351-385.

163. Viner N. Intractable sciatica-The sacral epidural injection-An effective method of giving pain relief. Can Med Asso J 1925;15:630-634.

164. Evans W. Intrasacral epidural injection in the treatment of sciatica. Lancet 1930;2:1225-1229.

165. Rovenstein EA, Wertheim HM. Therapeutic nerve block. JAMA 1941;117:1599-1603.

166. Robechhi A., Capra R. L'idrocortisone (composto F). Prime esperienze cliniche in campo reumatologico. Minerva Med 1952;98:1259-1263.

167. Lievre JA, Block-Michel H, Attali P. L'injection transscree etude clinique et radiologrique. Bull Soc Med Hop 1957;73:1110-1118.

168. Goebert HW, Jallo SJ, Gardner WJ et al. Painful radiculopathy treated with epidural injections of procaine and hydrocortisone acetate results in 113 patients. Anesth Analg 1961;140:130-134.

169. Steindler A. Luck JV. Differential diagnosis of pain in the low back: Allocation of the source of the pain by the procaine hydrochloride method. JAMA 1938;110:106-113.

170. Kappis M. Ueber leitungsanasthesie an Bauch, Burst, Arm und Hals durch Injektion ans Foramen intervertebrale. Munch Med Wochenschr 1912;1:794.

171. Wertheim HM, Rovenstine EA. Suprascapular nerve block. Anesthesiology 1941;2:541.

172. Sluijter ME, Koetsveld-Baart CC. Interruption of pain pathways in the treatment of cervical syndrome. Anaesthesia 1980;35:302-307.

173. Hildebrandt J, Argyrakis A. Percutaneous nerve block of the cervical facets - A relatively new method in the treatment of chronic headache and neck pain. Man Med 1986;2:48-52.

174. Okada K. Studies on the cervical facet joints using arthrography of the cervical facet joint. J Jpn Orthop Assoc 1981;55:563-580.

175. Fox AJ, Melzack R. Transcutaneous electrical stimulation to acupuncture. Comparison of treatment of low back pain. Pain 1976;2:141-148. 
176. Fowler RJ, Blackwell GJ. Anti-inflammatory steroid induced biosynthesis of a phospholipase A2 inhibitor which prevents prostaglandin generation. Nature 1979;278:456-459.

177. Devor M, Govrin-Lippmann R, Raber P. Corticosteroids suppress ectopic neural discharges originating in experimental neuromas. Pain 1985;22:127-137.

178. Hua SY, Chen YZ. Membrane receptor-mediated electrophysiological effects of glucocorticoid on mammalian neurons. Endocrinology 1989;124:687-691.

179. Johansson A, Hao J, Sjolund B. Local corticosteroid application blocks transmission in normal nociceptor C-fibers. Acta Anaesthesiol Scand 1990;34:335-338.

180. Faber LE, Wakim NG, Duhring JL. Evolving concepts in the mechanism of steroid action: Current developments. Am J Obstet Gynecol 1987; 156:1449-1458.

181. Olmarker K, Byrod G, Cornefijord M et al. Effects of methylprednisolone on nucleus pulposus-induced nerve root injury. Spine 1994;19:1803-1808.

182. Nicol GD, Klingberg DK, Vasko MR. Prostaglandin E2 enhances calcium conductance and stimulates release of substance $\mathrm{P}$ in avian sensory neurons. $J$ Neurosci 1992;12:1917-1927.

183. Coderre T. Contribution of protein kinase $\mathrm{C}$ to central sensitization and persistent pain following tissue injury. Neurosci Lett 1992;140:181-184.

184. Hayashi N, Weinstein JN, Meller ST et al. The effect of epidural injection of betamethasone or bupivacaine in a rat model of lumbar radiculopathy. Spine 1998;23:877-885.

185. Lee HM, Weinstein JN, Meller ST et al. The role of steroids and their effects on phospholipase A2. An animal model of radiculopathy. Spine 1998;23:11911196.

186. Manchikanti L. The value and safety of steroids in neural blockade. Am J Pain Management 2000; in press.

187. Minamide A, Tamaki T, Hashizume H et al. Effects of steroids and lipopolysaccharide on spontaneous resorption of herniated intervertebral discs. An experience study in the rabbit. Spine 1998; 23:870-876.

188. Johansson A, Bennett GJ. Effect of local methylprednisolone on pain in a nerve injury model. A pilot study. Regional Anesthesia 1997; 22:59-65.

189. Kingery WS, Castellote JM, Maze M. Methylprednisolone prevents the development of autotomy and neuropathic edema in rats, but has no effect on nociceptive thresholds. Pain 1999; 80: 555-566.

190. Fink BR, Cairns AM. Differential use-dependent (frequency-dependent) effects in single mammalian axons: Data and clinical considerations. Anesthesiology 1987;67:477-484.

191. Li Yue-Ming, Wingrove DE, Too HP et al. Local anesthetics inhibit substance $\mathrm{P}$ binding and evoked increases in intracellular $\mathrm{Ca}^{2}+$. Anesthesiology 1995:82:166-173
192. Bonica JJ, Backup PH, Anderson CE. Peridural block, an analysis of 3,637 cases. A review. Anesthesiology 1957; 18:723-734.

193. Postacchini F. Results of surgery compared with conservative management for lumbar disc herniations. Spine 1996;21:1383-1387.

194. Malter AD, Larwon EB, Urban N et al. Cost-effectiveness of lumbar discectomy for the treatment of herniated intervertebral disc. Spine 1996;21:10481055.

195. Mayer TG, Polatin P, Smith B et al. Spine rehabilitation. Secondary and tertiary nonoperative care. Spine 1995;20:2060-2066.

196. Teasell RW, Harth M. Functional restoration. Returning patients with chronic low back pain to work-Revolution or fad? Spine 1996;21:844-847.

197. Kikuchi S, Hasue M, Nishiyama K. Anatomic and clinical studies of radicular symptoms. Spine 1984;9:23-30.

198. Van der Windt DAWM, van der Jeijden GJMG, van den Berg SGM et al. Ultrasound therapy for musculoskeletal disorders. A systematic review. Pain 1999; 81:257-271.

199. Hurwitz EL, Aker PD, Adams AH et al. Manipulation and mobilization of the cervical spine. A systematic review of the literature. Spine 1996; 21:1746-1760.

200. Faas A, van Eijk JTM, Chavannes AW et al. A randomized trial of exercise therapy in patients with acute low back pain. Efficacy of sickness absence. Spine 1995; 20:941-947.

201. Grant DJ, Bishop-Miller J, Winchester DM, Anderson $\mathrm{M}$, Faulkner S. A randomized comparative trial of acupuncture versus transcutaneous electrical nerve stimulation of chronic back pain in the elderly. Pain 1999; 82:9-13.

202. Cauchoix J, Ficat C, Girard B. Repeat surgery after disc excision. Spine 1978; 3:256-289.

203. Pawl RP. Arachnoiditis and epidural fibrosis. The relationship to chronic pain. Current Review of Pain 1998; 2:93-99.

204. Van Tulder MW, Cherkin DC, Berman B et al. The effectiveness of acupuncture in the management of acute and chronic low back pain. A systematic review within the framework of the Cochrane Collaboration Back Review Group. Spine 1999; 24:1113-1123.

205. Airaksinen O, Herno A, Turunen V et al. Surgical outcome of 438 patients treated surgically for lumbar spine stenosis. Spine 1997; 22:2278-2282.

206. Skargren EI, Carlsson PG, Öberg BE. One-year follow-up comparison of the cost and effectiveness of chiropractic and physiotherapy as primary management for back pain. Subgroup analysis, recurrence, and additional health care utilization. Spine 1998; 23:18751884.

207. Klekamp J, McCarty E, Spengler DM. Results of elective lumbar discectomy for patients involved in the 
workers' compensation system. J Spinal Disord 1998; 11:277-282

208. Cassisi JE, Sypert GW, Salamon A et al. Independent evaluation of a multidisciplinary rehabilitation program for chronic low back pain. Neurosurgery 1989; 25:877883.

209. Robinson JP, Allen T, Fulton LD et al. Perceived efficacy of pain clinics in the rehabilitation of injured workers. Clin J Pain 1998; 14:202-208.

210. Triano JJ, McGregor M, Hondras MA et al. Manipulative therapy versus education programs in chronic low back pain. Spine 1995; 20:469-472.

211. Stankovic R, Johnell O. Conservative treatment of acute low back pain. A 5-year follow-up study of two methods of treatment. Spine 1995; 20:469-472.

212. Mayer T, McMahon MJ, Gatchel RJ et al. Socioeconomic outcomes of combined spine surgery and functional restoration in workers' compensation spinal disorders with matched controls. Spine 1998; 23:598606.

213. Wheeler AH, Hanley EN Jr. Nonoperative treatment for low back pain. Rest to restoration. Spine 1995; 20:375-378.

214. Morley S, Eccleston C, Williams A. Systematic review and meta-analysis of randomized controlled trials of cognitive behavior therapy for chronic pain in adults, excluding headache. Pain 1999; 90:1-13.

215. Stein M, Elliott D, Glen J et al. Percutaneous facet joint fusion. Preliminary experiences. Vasc Interv Radiol 1993; 4:69-74.

216. Marks RC, Houston T, Thulbourne T. Facet joint injection and facet nerve block. A randomized comparison in 86 patients with chronic low back pain. Pain 1992; 49:325-328.

217. Nash TP. Facet joints. Intra-articular steroids or nerve blocks? Pain Clinic 1990; 3:77-82.

218. Barnsley L, Bogduk N. Medial branch blocks are specific for the diagnosis of cervical zygapophyseal joint pain. Reg Anesth 1993;18:343-350.

219. Dreyfuss P, Schwarzer AC, Lau P et al. Specificity of lumbar medial branch and L5 dorsal ramus blocks: A computed tomography study. Spine 1997; 22:895-902.

220. Bogduk N, Long DM. Percutaneous lumbar medial branch neurotomy. A modification of facet denervation. Spine 1980;5:193-200.

221. Bogduk N, Macintosh J, Marsland A. Technical limitations to the efficacy of radiofrequency neurotomy for spinal pain. Neurosurgery 1987;20:529-535.

222. Lord SM, Barnsley L, Wallis BJ et al. Percutaneous radio-frequency neurotomy for chronic cervical zygapophyseal-joint pain. $N$ Eng J Med 1996;335:1721-1726.

223. Schaerer JP. Treatment of prolonged neck pain by radiofrequency facet rhizotomy. J Neurol Orthop Med Surg 1988;9:74-76.

224. Vervest ACM, Stolker RJ. The treatment of cervical pain syndromes with radiofrequency procedures. Pain Clinic 1991;4:103-112.

225. Slivers RH. Lumbar percutaneous facet rhizotomy. Spine 1990;15:36-40.

226. Onofrio BM, Campa HK. Evaluation of rhizotomy. Review of 12 years experience. J Neurosurg 1972; 36: 151-155.

227. Brechner T. Percutaneous cryogenic neurolysis of the articular nerve of Luschka. Reg Anesth 1981; 6:1822.

228. North RB, Han M, Zahurak M et al. Radiofrequency lumbar facet denervation: Analysis of prognostic factors. Pain 1994; 57:77-83.

229. Schaerer JP. Radiofrequency facet rhizotomy in the treatment of chronic neck and low back pain. Int Surg 1978; 63:53-59.

230. Gallagher J, Vadi PLP, Wesley JR. Radiofrequency facet joint denervation in the treatment of low back pain - A prospective controlled double-blind study to assess efficacy. Pain Clinic 1994;7:193-198.

231. Ogsbury JS, Simon RH, Lehman RAW. Facet "denervation" in the treatment of low back syndrome. Pain 1977;3:257-263.

232. Shealy CN. Percutaneous radiofrequency denervation of spinal facets. J Neurosurg 1975; 43:448-451.

233. Sluijter ME, Mehta M. Treatment of chronic back and neck pain by percutaneous thermal lesions. In: Lipton $\mathrm{S}$ (ed). Persistent pain, Modern methods of treatment. London, Academic Press, 1981; pp141-179.

234. Sluijter ME. The use of radiofrequency lesions of the communicating ramus in the treatment of low back pain. In: Racz GB (ed). Techniques of neurolysis. Boston, Kluwer Academic Publishers; 1989: pp145160

235. Dreyfuss P. Lumbar radiofrequency neurotomy for chronic zygapophysial joint pain. A pilot study using dual medial branch blocks. ISIS Newsletter 1999; 3:1333.

236. Shealy CN. Facet denervation in the management of back sciatic pain. Clin Orthop 1976; 115:157-164.

237. Mehta M, Sluijter ME. The treatment of chronic pain. Anesthesia 1979; 34:768-775.

238. Rashbaum RF. Radiofrequency facet denervation. A treatment alternative in refractory low back pain with or without leg pain. Orthop Clin North Am 1983; 14:569-575.

239. Banerjee T, Pittman HH. Facet rhizotomy. Another armamentarium for treatment of low backache. $N C$ Med J 1976; 37:354-360.

240. Burton CB. Percutaneous radiofrequency facet denervation. Appl Neurophysiol 1976/77; 39:80-86.

241. Ignelzi RJ, Cummings TW. A statistical analysis of percutaneous radiofrequency lesions in the treatment of chronic low back pain and sciatica. Pain 1980; 8:181-187.

242. Katz SS, Savitz MH. Percutaneous radiofrequency 
rhizotomy of the lumbar facets. Mt Sinai J Med 1986; 7:523-525.

243. Koning HM, Mackie DP. Percutaneous radiofrequency facet denervation in low back pain. Pain Clinic 1994; 7:199-204.

244. Oudenhoven RC. The role of laminectomy, facet rhizotomy, and epidural steroids. Spine 1979; 4:145-147.

245. Savitz MH. Percutaneous radiofrequency rhizotomy of the lumbar facets. Ten years experience. Mt Sinai J Med 1991; 58:177-178.

246. Uematsu S, Udvarhelyi GB, Benson DW et al. Percutaneous radiofrequency rhizotomy. Surg Neurol 1974; 2:319-325.

247. Van Kleef M, Barendse GAM, Kessels A et al. Randomized trial of radiofrequency lumbar facet denervation for chronic low back pain. Spine 1999; 24:19371942.

248. Sluijter ME. The use of radiofrequency lesions for pain relief in failed back patients. Int Disabil Studies 1988; 10:37-43.

249. Wallis BJ, Lord SM, Bogduk N. Resolution of psychological distress of whiplash patients following treatment by radiofrequency neurotomy: A randomized, double-blind, placebo-controlled trial. Pain 1997;73:15-22.

250. Van Kleef M, Liem L, Lousberg R et al. Radiofrequency lesions adjacent to the dorsal root ganglion for cervicobrachial pain. A prospective double blind randomized study. Neurosurgery 1996;38:1-6.

251. Van Kleef AR, Spaans F, Digemavs W et al. Effects and side effects of percutaneous thermal lesions of the dorsal root ganglion in patients with cervical pain syndromes. Pain 1993;52:49-53.

252. Hove B, Glydensted C. Cervical analgesia facet joint arthrography. Neuroradiology 1990;32:456-459.

253. Roy DF, Fleury J, Fontaine SB et al. Clinical evaluation of cervical facet joint infiltration. Can Assoc Radiol J 1988;39:118-120.

254. Dusault DG, Nicolet VM. Cervical facet joint arthrography. J Can Assoc Radiol 1985;36:79-80.

255. Wedel DJ, Wilson PR. Cervical facet arthrography. Reg Anesth 1985;10:7-11.

256. Barnsley L, Lord SM, Wallis BJ et al. Lack of effect of intra-articular corticosteroids for chronic pain in the cervical zygapophyseal joints. N Engl J Med 1994;330:1047-1050.

257. Bovim G, Berg R, Dale LG. Cervicogenic headache: Anesthetic blockades of cervical nerves (C2-C5) and facet joint (C2/C3). Pain 1992;49:315-320.

258. Fukusaki M, Tsuji K, Fujie T et al. The effects of blockade of the facet joint of the Atlas and Axis upon muscle tension headaches. Headache 1990;4:312-317.

259. Carette S, Marcoux S, Truchon R et al. A controlled trial of corticosteroid injections into facet joints for chronic low back pain. N Engl J Med 1991; 325:10021007.
260. Carrera GF. Lumbar facet joint injection in low back pain and sciatica: Preliminary results. Radiology 1980; 137:665-667.

261. Fairbank JCT, Park WM, McCall IW et al. Apophyseal injection of local anesthetic as a diagnostic aid in primary low back pain syndromes. Spine 1981; 6:598605.

262. Desoutet JM, Gilula LA, Murphy WA et al. Lumbar facet joint injection: Indication, technique, clinical correlation, and preliminary results. Radiology 1982; 145:321-325.

263. Raymond J, Dumas JM. Intra-articular facet block: Diagnostic tests or therapeutic procedure? Radiology 1989;151:333-336.

264. Lippitt AB. The facet joint and its role in spine pain. Management with facet joint injections. Spine 1984;9:746-750.

265. Lau LS, Littlejohn GO, Miller MH. Clinical evaluation of intra-articular injections for lumbar facet joint pain. Med J Aust 1985;143:563-565.

266. Lewinnek GE, Warfield CA. Facet joint degeneration as a cause of low back pain. Clin Orthop 1986;213:216-222.

267. Murtagh FR. Computed tomography and fluoroscopy guided anesthesia and steroid injection in facet syndrome. Spine 1988; 13:686-689.

268. Helbig T, Lee CK. The lumbar facet syndrome. Spine 1988; 13:61-64.

269. Moran R, O'Connell D, Walsh MG. The diagnostic value of facet joint injections. Spine 1986;12:14071410 .

270. Lilius G, Laasonen EM, Myllynen P et al. Lumbar facet joint syndrome. A randomized clinical trial. $J$ Bone Joint Surg (Br) 1989; 71:681-684.

271. Lynch MC, Taylor JF. Facet joint injection for low back pain. A clinical study. J Bone Joint Surg (Br) 1986;68:138-141.

272. Dory MA. Arthrography of the lumbar facet joints. Radiology 1981; 140:23-27.

273. McCormick CC. Arthrography of the atlanto-axial (C1-C2) joints: Technique and results. J Intervent Radiol 1987;2:9.

274. Weinstein SM, Herring SA, Derby R. Epidural steroid injections. Spine 1995; 20:1842-1846.

275. Savolaine ER, Pandya JB, Greenblat SH et al. Anatomy of the human lumbar epidural space: New insights using CT-epidurography. Anesthesiology 1988;68:217220.

276. Hogan QH. Epidural anatomy examined by cryomicrotome section. Influence of age, vertebral level and disease. Reg Anesth 1996;21:295-306.

277. Tajima T, Furukawa K, Kuramocji E. Selective lumbosacral radiculography and block. Spine 1980;5:6877.

278. White AH, Derby R, Wynne G. Epidural injections for diagnosis and treatment of low back pain. Spine 
1980;5:78-86.

279. Winnie AP, Hartman JT, Meyers HL et al. Pain Clinic II: Intradural and extradural corticosteroids for sciatica. Anesth Analg 1972;51:990-1003.

280. Sehgal AD, Tweed DC, Gardner WS. Laboratory studies after intrathecal corticosteroids. Arch Neurol 1963;9:64-68.

281. Swerdlow M, Sayle-Creer W. A study of extradural medication in the relief of three lumbosciatic syndromes. Anaesthesia 1970;25:341-345.

282. Manchikanti L, Bakhit CE, Pampati V. Role of epidurography in caudal neuroplasty. Pain Digest 1998;8:277-281.

283. Renfrew DL, Moore TE, Kathol MH et al. Correct placement of epidural steroid injections: Fluoroscopic guidance and contrast administration. Amer $J$ Neuroradiol 1991;12:1003-1007.

284. Stewart HD, Quinnell RC, Dann N. Epidurography in the management of sciatica. Br J of Rheum 1987; 26:424-429.

285. El-Khoury G, Ehara S, Weinstein JW et al. Epidural steroid injection: A procedure ideally performed with fluoroscopic control. Radiology 1988; 168:554-557.

286. Fredman B, Nun MB, Zohar E et al. Epidural steroids for treating "failed back surgery syndrome": Is fluoroscopy really necessary? Anesth Analg 1999; 88:367372.

287. Stitz MY, Sommer HM. Accuracy of blind versus fluoroscopically guided caudal epidural injection. Spine 1999; 24:1371-1376.

288. Mehta M, Salmon N. Extradural block. Confirmation of the injection site by X-ray monitoring. Anaesthesia 1985; 40:1009-1012.

289. Nishimura N, Khahara T, Kusakabe T. The spread of lidocaine and 1-131 solution in the epidural space. Anesthesiology 1959;20:785-788.

290. Burn JM, Guyer PB, Langdon L. The spread of solutions injected into the epidural space: A study using epidurograms in patients with lumbosciatic syndrome. Br J Anaesth 1973;45:338-345.

291. Hodgson PSA, Mack B, Kopacz D et al. Needle placement during lumbar epidural anesthesia deviates toward the non-dependent side (abstract). Reg Anesth 1996;21:26.

292. Bromage RP, Benumof JL. Paraplegia following intracord injection during attempted epidural anesthesia under general anesthesia. Reg Anesth and Pain Med 1998; 23:104-107.

293. Krane EJ, Dalens BJ, Murat I, et al The safety of epidurals during general anesthesia. Reg Anesth and Pain Med 1998; 23:433-438.

294. Hodges SD, Castleberg RL, Miller T et al. Cervical epidural steroid injection with intrinsic spinal cord damage. Two case reports. Spine 1998; 23:2137-2142.

295. Derby R. Point of view. Spine 1998; 23:2141-2142.

296. Manchikanti L. Epidural steroid injections and intrin- sic spinal cord damage. Spine 1999;24:1170-1171.

297. Saberski LR, Kondamuri S, Osinubi OYO. Identification of the epidural space: Is loss of resistance to air a safe technique? Regional Anesthesia 1997; 22:3-15.

298. Coomes EN. A comparison between epidural anesthesia and bedrest in sciatica. Brit Med J 1961;1:2024.

299. Cuckler JM, Bernini PA, Wiesel SW et al. The use of epidural steroid in the treatment of radicular pain. $J$ Bone Joint Surg 1985;67:63-66.

300. Dilke TFW, Burry HC, Grahame R. Extradural corticosteroid injection in the management of lumbar nerve root compression. Br Med J 1973;2:635-637.

301. Helliwell M, Robertson JC, Ellia RM. Outpatient treatment of low back pain and sciatica by a single extradural corticosteroid injection. Br J Clin Pract 1985;39:228-231.

302. Klenerman L, Greenwood R, Davenport HT et al. Lumbar epidural injections in the treatment of sciatica. Br J Rheumatol 1984;23:35-38.

303. Ridley MG, Kingsley GH, Gibson T et al. Outpatient lumbar epidural corticosteroid injection in the management of sciatica. Br J Rheumatol 1988;27:10031007.

304. Rocco AG, Frank E, Kaul AF et al. Epidural steroids, epidural morphine and epidural steroids combined with morphine in the treatment of post-laminectomy syndrome. Pain 1989;36:297-303.

305. Serrato JM, Marks RL, Morley SJ et al. Intrathecal midazolam for the treatment of chronic mechanical low back pain: A controlled comparison with epidural steroid in a pilot study. Pain 1992;48:5-12.

306. Snoek W, Weber H, Jorgensen B. Double-blind evaluation of extradural methyl/prednisolone for herniated lumbar disc. Acta Orthop Scand 1977;48:635-641.

307. Berman AT, Garbarinbo JL, Fisher SM et al. The effects of epidural injection of local anesthetics and corticosteroids in patients with lumbosciatic pain. Clin Orthop 1984;188:144-151.

308. Brown FW. Management of discogenic pain using epidural and intrathecal steroids. Clin Orthop 1977;129:72-78.

309. Warr AC, Wilkinson JA, Burn JMB et al. Chronic lumbosciatica syndrome treated by epidural injection and manipulation. Practitioner 1977;209:53-59.

310. Hickey RF. Outpatient epidural steroid injections for low back pain and lumbosacral radiculopathy. NZMed J 1987;100:54-59.

311. Heyse-Moore GH. A rational approach to the use of epidural medication in the treatment of sciatic pain. Acta Orthop Scand 1978;49:366-370.

312. Harley C. Extradural corticosteroid infiltration. A follow-up study of 50 cases. Ann Phy Med 1966;9:2228.

313. Manchikanti L, Pakanati RR, Pampati V. Comparison of three routes of epidural steroid injections in low back 
pain. Pain Digest 1999;9:277-285.

314. Sharma S, Stedman R. Epidural steroids. A retrospective analysis of the efficacy of high and low dose therapy. Anesthesiology 1998; 3A:A1135.

315. Rosen CD, Kahanovitz N, Berstein R et al. A retrospective analysis of the efficacy of epidural steroid injections. Clin Orthop 1988;228:270-272.

316. Jamison RN, VadeBoncouer T, Ferrante FM. Low back pain patients unresponsive to an epidural steroid injection: Identifying predictive factors. Clin J Pain 1991; 7:311-317.

317. Fukusaki M, Kobayashi I, Hara T et al. Symptoms of spinal stenosis do not improve after epidural steroid injection. Clin J Pain 1998;14:148-151.

318. Rogers P, Nash T, Schiller D et al. Epidural steroids for sciatica. The Pain Clinic 1992; 5:67-72.

319. Catchlove RFH, Braha R. The use of cervical epidural nerve blocks in the management of chronic head and neck pain. Can Anaesth Soc J 1984;31:188-191.

320. Bush K, Hillier S. Outcome of cervical radiculopathy treated with periradicular/epidural corticosteroid injections: A prospective study with independent clinical review. Eur Spine J 1996;5:319-325.

321. Purkis IE. Cervical epidural steroids. Pain Clinic 1986;1:3-7.

322. Rowlingson JC, Kirschenbaum LP. Epidural analgesic techniques in the management of cervical pain. Anesth Analg 1986;65:938-942.

323. Warfield CA, Biber MP, Crews DA et al. Epidural steroid injection as a treatment for cervical radiculitis. Clin J Pain 1988;4:201-204.

324. Castagnera L, Maurette P, Pointillart V et al. Longterm results of cervical epidural steroid injection with and without morphine in chronic cervical radicular pain. Pain 1994;58:239-243.

325. Stav A, Ovadia L, Sternberg A et al. Cervical epidural steroid injection for cervicobrachialgia. Acta Anaesthesiol Scand 1993;37:562-566.

326. Cicala RS, Thoni K, Angel JJ. Long-term results of cervical epidural steroid injections. Clin J Pain 1989;5:143-145.

327. Pawl RP, Anderson W, Shulman M. Effect of epidural steroids in the cervical and lumbar region on surgical intervention for discogenic spondylosis. In: Fields HL (ed). Advances in pain research and therapy. New York, Raven Press, 1985; Vol. 9; pp791-798.

328. Breivik H, Hesla PE, Molnar I et al. Treatment of chronic low back pain and sciatica. Comparison of caudal epidural injections of bupivacaine and methylprednisolone with bupivacaine followed by saline. In: Bonica JJ, Albe-Fesard D (eds). Advances in pain research and therapy. New York, Raven Press, 1976; Vol 1; pp927-32.

329. Bush K, Hillier S. A controlled study of caudal epidural injections of triamcinolone plus procaine for the management of intractable sciatica. Spine
1991;16:572-575.

330. Czarski Z. Leczenie rwy kulszowej wstrzykiwaniem hydrokortyzonu inowokainy do rozworu kryzowego. Przeglad Kekarski 1965;21:511-513.

331. Daly P. Caudal epidural anesthesia in lumbosciatic pain. Anesthesia 1970;25:346-348.

332. Matthews JA, Mills SB, Jenkins VM et al. Back pain and sciatica: Controlled trials of manipulation, traction, sclerosant and epidural injections. Brit $J$ Rheumatol 1987;26:416-423.

333. Yates DW. A comparison of the types of epidural injection commonly used in the treatment of low back pain and sciatica. Rheum Rehab 1978;17:181-186.

334. Beliveau P. A comparison between epidural anesthesia with and without corticosteroids in the treatment of sciatica. Rheum Phys Med 1971;11:40-43.

335. Gardner HW, Jallo SJ, Gardner WJ et al. Painful radiculopathy treated with epidural injections of procaine and hydrocortisone acetate. Results in 113 patients. Anesth Analg 1961;140:130-134.

336. Ombregt L, Ter Veer HJ. Treatment of the lumbar spine. In: Ombregt L, Bisschop P, Ter Veer HJ et al (eds). A system of orthopaedic medicine. London, WB Saunders 1995;pp633-688.

337. Ciocon JO, Galindo-Clocon D, Amarnath L et al. Caudal epidural blocks for elderly patients with lumbar canal stenosis. J Am Geriatr Soc 1994;42:593-596.

338. Mount HTR. Epidural injection of hydrocortisone for the management of the acute lumbar disc protrusion. In: Morley TP (ed). Current controversies in neurosurgery. Philadelphia, Saunders, 1976, pp 67-72.

339. Forrest JB. Management of chronic dorsal root pain with epidural steroids. Can Anesth Soc J 1978; 25:218.

340. Perkins HM, Hanlon PR. Epidural injection of local anesthetic and steroids for pain secondary to herpes zoster. Arch Surg 1978; 113:253.

341. Derby R, Kine G, Saal JA et al. Response to steroid and duration of radicular pain as predictors of surgical outcome. Spine 1992;17 (Suppl):176-183.

342. Weiner BK, Fraser RD. Foraminal injection for lateral lumbar disc herniation. J Bone Joint Surg 1997;79B:804-807.

343. Devulder, J. Transforaminal nerve root sleeve injection with corticosteroids, hyaluronidase, and local anesthetic in the failed back surgery syndrome. J Spinal Disord 1998;11:151-154.

344. Lutz GE, Vad VB, Wisneski RJ. Fluoroscopic transforaminal lumbar epidural steroids: An outcome study. Arch Phys Med Rehabil 1998; 79:1362-1366.

345. Slipman CW, Plastaras CT, Palmitier RA et al. Symptom provocation of fluoroscopically guided cervical nerve root stimulation. Are dynatomal maps identical to dermatomal maps? Spine 1998; 23:2235-2242.

346. Lutz GE, Vad VB, Wisneski RJ. Fluoroscopic transforaminal lumbar epidural steroids. An outcome study. Presented at ISIS 7th Annual Scientific Meeting, Las 
Vegas, Nev. August 1999.

347. Riew KD, Yin Y, Gilula L, et al. Can nerve root injections obviate the need for operative treatment of lumbar radicular pain? A prospective, randomized, controlled, double-blind study. Proceedings of North American Spine Society 16th Annual Meeting, Chicago. 1999; 94-95.

348. Manchikanti L, Bakhit CE, Pakanati RR et al. Fluoroscopy is medically necessary for the performance of epidural steroids. Anesth Analg 1999; 89:1326-1327.

349. Racz GB, Heavner JE, Diede JH. Lysis of epidural adhesions utilizing the epidural approach. In: Waldman $\mathrm{SD}$, Winnie AP (eds). Interventional pain management. Philadelphia, W.B. Saunders, 1996;pp339-351.

350. Racz GB, Holubec JT. Lysis of adhesions in the epidural space. In: Racz GB (ed). Techniques of neurolysis. Boston, Kluwer Academic Publishers, 1989;pp57-72.

351. Racz GB, Sabonghy M, Gintautas J et al. Intractable pain therapy using a new epidural catheter. JAMA 1982;248:579-581.

352. Racz GB, Haynsworth RF, Lipton S. Experiences with an improved epidural catheter. Pain Clinic 1986;1:2127.

353. Racz GB, Heavner JE, Sigleton W et al. Hypertonic saline and corticosteroid injected epidurally for pain control. In: Racz GB (ed). Techniques of neurolysis. Boston, Kluwer Academic Publishers, 1989;pp73-94.

354. Lewandowski EM. The efficacy of solutions used in caudal neuroplasty. Pain Digest 1997;7:323-330.

355. Arthur J, Racz G, Heinrich R et al. Epidural space: Identification of filling defects and lysis of adhesions in the treatment of chronic painful conditions. $A b$ stracts, 7th World Congress on Pain. Paris, IASP Publications, 1993;pp557.

356. Manchikanti L. Pakanati RR, Bakhit CE et al. Role of adhesiolysis and hypertonic saline neurolysis in management of low back pain. Evaluation of Modification of Racz Protocol. Pain Digest, 1999; 9:91-96..

357. Racz GB, Heavner JE, Raj PP. Percutaneous epidural neuroplasty. Prospective one-year follow up. Pain Digest 1999; 9:97-102.

358. Heavner JE, Racz GB, Raj P. Percutaneous epidural neuroplasty. Prospective evaluation of $0.9 \% \mathrm{NaCl}$ versus $10 \% \mathrm{NaCl}$ with or without hyaluronidase. Reg Anesth Pain Med 1999; 24:202-207.

359. Manchikanti L, Pakanati RR, Bakhit CE, et al. Nonendoscopic and endoscopic adhesiolysis in post lumbar laminectomy syndrome. A one-year outcome study and cost effectiveness analysis. Pain Physician 1999; 2:52-58.

360. Manchikanti L, Bakhit CE. Percutaneous epidural adhesiolysis. Pain Physician 2000; 3:46-64.

361. Devulder J, Lutgarde B, Castille F et al. Relevance of epidurography and epidural adhesiolysis in chronic failed back surgery patients. Clin J Pain 1995;11:147150 .
362. Saberski LR, Kitahata LM. Direct visualization of the lumbosacral epidural space through the sacral hiatus. Anesth Analg 1995:80:839-840.

363. Saberski LR, Brull S. Fiberoptic visualization of the spinal cord. A historical review and report of current methods. Yale Biol Med 1995:68:7-16.

364. Manchikanti L, Pakanati RR, Pampati V. The value and safety of epidural endoscopic adhesiolysis. Amer $J$ Anesthesiology 2000; in press.

365. Smith G. The normal discogram. Am J Radiol 1959;81:1006-1010.

366. Parfenchuck T, Janssen M. A correlation of cervical magnetic resonance imaging and discography-computed tomographic discograms. Spine 1994;19:28192825.

367. Roth O. Cervical analgesic discography: A new test for the definitive diagnosis of the painful-disc syndrome. JAMA 1976;235:1713-1714.

368. Shinomiya K, Nakao N, Shindoh K et al. Evaluation of cervical discography in pain origin and provocation. J Spinal Disord 1993;6:422-426.

369. Simmons E. An evaluation of discography in the localization of symptomatic levels in discogenic diseases of the spine. Clin Orthop 1975;108:57-59.

370. Schellhas KP, Smith MD, Gundry CR et al. Cervical discogenic pain. Spine 1996;21:300-311.

371. Holt E. Fallacy of cervical discography. JAMA 1964;188:799-801.

372. Bogduk N. The argument for discography. Neurosurgery Quarterly 1996; 6:152-153.

373. Vanharanta H, Sachs BL, Spivey MA et al. The relationship of pain provocation to lumbar disc deterioration as seen by CT/discography. Spine 1987; 12:295298.

374. Moneta GB, Videman T, Kaivanto K et al. Reported pain during lumbar discography as a function of anular ruptures and disc degeneration: a re-analysis of 833 discograms. Spine 1994; 17:1968-1974.

375. The Executive Committee of the North American Spine Society. Position statement on discography. Spine 1988;13:1343.

376. Guarino AH. Discography. A review. Current Review of Pain 1999; 3:473-480.

377. Van Kleef M, Barendse GA. Percutaneous intradiscal radiofrequency thermocoagulation in chronic non-specific low back pain. Pain Clinic 1996;3:259-268.

378. Saal JS, Saal JA, Park M. Percutaneous treatment of painful lumbar disc derangement with a navigable intradiscal thermal catheter. A pilot study. NASS-APS First Joint Meeting, Charleston, SC, April 1998.

379. Derby R, Eek BC, Saal JA. Intradiscal electrothermal coagulation by catheter. IITS Eleventh Annual Meeting, San Antonio, TX, May 1998.

380. Saal JA, Saal JS, Ashley J et al. Thermal characteristics and the lumbar disc. Evaluation of a novel approach to targeted intradiscal thermal therapy. NASS- 
APS First Joint Meeting, Charleston, SC, April 1998.

381. Saal JA. Intradiscal electrothermal annuloplasty (IDET) treatment for chronic multilevel discogenic pain. Prospective one year follow up outcome study. Presented at combined IITS/ISMISS Meeting. Cambridge, UK August 1-5, 1999.

382. Saal JA. Lumbar intradiscal electrothermal therapy (IDET). Presented at the 6th International Meeting on Advanced Spine Techniques. Vancouver, BC July 610, 1999.

383. Saal J, Saal J. A novel approach to painful internal disc derangement. Collagen modulation with a thermal percutaneous navigable intradiscal catheter - A prospective trial. Presented at the meeting of the International Society for the Study of Lumbar Spine. Kona, Hawaii June 21-25, 1999.

384. Derby R, Eek B, Ryan D. Intradiscal electrothermal annuloplasty - 12 month follow up pilot study. Presented at the meeting of the International Society for the Study of the Lumbar Spine. Kona, Hawaii June 21-25, 1999.

385. O’Neill C, Derby R, Kenderes L. Precision injection techniques for diagnosis and treatment of lumbar disc disease. Seminars in Spine Surgery 1999; 11:104-118.

386. Saal JS, Saal JA. A novel approach to painful internal disc derangement. Collagen modulation with a thermal percutaneous navigable intradiscal catheter. A prospective trial. Presented at the 13th annual meeting of the North American Spine Society. San Francisco, CA October 28-31, 1998.

387. Derby R, Eek B, Ryan D. Intradiscal electrothermal annuloplasty. Presented at the 13th annual meeting of the North American Spine Society. San Francisco, CA October 28-31, 1998.

388. Dreyfuss P. Percutaneous interventions for intrinsic disc pain in the lumbar spine. Scientific Newsletter of the International Spinal Injection Society 1998; 3:1.

389. Saberski LR, Ahmad M, Fitzgerald J et al. Practice patterns in the use of epidural corticosteroid injections. A survey of the Connecticut State Society of Anesthesiologists. Poster Exhibits. Anesthesiology 1998; 101.

390. Jurmand SH. Cortiotherapie peridurale des lombalgies et des sciatiques d'origine discale. Concours Medicale 1972;94:5061-5070.

391. Ito R. The treatment of low back pain and sciatica with epidural corticosteroids injection and its pathophysiologic basis. J Jpn Orthop Assoc 1971;45:769777.

392. Hopwood M. Outcomes assessment in pain management. In: Abram SE (Ed). Pain Management. Philadelphia, Churchill-Livingston, 1998, pp14.1-14.11.

393. Piccirillo JF. Outcomes research and otolaryngology. Otolaryngol Head Neck Surg 1994; 111:764-769.

394. Ross Davies A, Doyle AT, Lansky D et al. Outcomes assessment in clinical settings: A consensus statement on principles and best practices in project management.
Joint Commission Journal on Quality Improvement 1994;20(1)6-16.

395. The Foundation for Health Services Research. Health Outcomes Research Primer. The foundation for Health Services Research, Washington, DC, 1994.

396. Epstein RS, Sherwood LM. From outcomes research to disease management: A guide for the perplexed. Ann Intern Med 1996; 124:832-837.

397. Greenfield S, Kaplan SH, Silliman RA et al. The uses of outcomes research for medical effectiveness, quality of care, and reimbursement in Type II diabetes. Diabetes Care 1994; 17:32-39.

398. Lynn J, Virnig BA. Assessing the significance of treatment effects: Comments from the perspective of ethics. Med Care 1995; 33:AS292-AS298.

399. Wilson IB, Kaplan S. Clinical practice and patient health status: how are the two related? Med Care 1995; 33:AS209-AS214.

400. Fowler FJ. Using patient reports to evaluate medical outcomes. United States Congress, Office of Technology Assessment. Tools for Evaluating Health Technologies. Five Background Paper, BP-H-142. Washington, DC, U.S. Government Printing Office, February, 1995.

401. Cicala RS, Wright H. Outpatient treatment of patients with chronic pain. Analysis of cost savings. Clin J Pain 1989;5:223-226.

402. Koes BW, Assendelft WJJ, Heijden GJMG van der et al. Spinal manipulation and mobilization for back and neck pain: A blinded review. Br Med J 1991;303:12981303.

403. Koes BW, Bouter LM, Mameren $\mathrm{H}$ van, et al. A blinded randomized clinical trial of manual therapy and physiotherapy for chronic back and neck complaints: Physical outcome measures. J Manipulative Physiol Ther $1992 ; 1: 16-23$

404. Guo HR, Tanaka S, Halperin WE et al. Back pain prevalence in US industry and estimates of lost work days. Am J Public Health 1999; 89:1029-1035.

405. Mueller-Schwefeg, Hassenbusch SJ, Reig E. Cost-effectiveness of intrathecal therapy for pain. Neuromodulation 1999; 2:77-84.

406. Lave JR, Frank RG, Schulberg HC et al. Cost effectiveness of treatments for major depression in primary care practice. Arch Gen Psychiatry 1998; 55:645-651.

407. Barnsley L, Lord S, Bogduk N. Comparative local anesthetic blocks in the diagnosis of cervical zygapophysial joints pain. Pain 1993; 55:99-106.

408. Lord SM, Barnsley L, Bogduk N. The utility of comparative local anesthetic blocks versus placebo-controlled blocks for the diagnosis of cervical zygapophysial joint pain. Clin J Pain 1995; 11:208213.

409. Schwarzer AC, Aprill CN, Derby R et al. The falsepositive rate of uncontrolled diagnostic blocks of the lumbar zygapophysial joints. Pain 1994; 58:195-200. 
410. International Classification of Diseases, Ninth Revision, Clinical Modification. ICD-9-CM. Reston, St. Anthony Publishing, 1998.

411. Current procedural terminology, CPT 1999, American
Medical Association, Chicago, 1998.

412. Current procedural terminology, CPT 2000, American Medical Association, Chicago, 1999. 